University of Rhode Island

DigitalCommons@URI

Open Access Master's Theses

1990

\title{
Expanding Housing Resources for the Physically Disabled People in Providence Through the Providence Housing Authority
}

Anne Cunningham

University of Rhode Island

Follow this and additional works at: https://digitalcommons.uri.edu/theses

\section{Recommended Citation}

Cunningham, Anne, "Expanding Housing Resources for the Physically Disabled People in Providence Through the Providence Housing Authority" (1990). Open Access Master's Theses. Paper 626. https://digitalcommons.uri.edu/theses/626 in Open Access Master's Theses by an authorized administrator of DigitalCommons@URI. For more information, please contact digitalcommons-group@uri.edu. 
EXPANDING HOUSING RESOURCES FOR THE PHYSICALLY DISABLED PEOPLE IN PROVIDENCE THROUGH THE PROVIDENCE HOUSING AUTHORITY

BY

ANNE CUNNINGHAM

A RESEARCH PROJECT SUBMITTED IN

PARTIAL FULFILLMENT OF THE REQUIREMENTS

FOR THE DEGREE OF MASTER

OF COMMUNITY PLANNING

THE UNIVERSITY OF RHODE ISLAND

AT KINGSTON

FALL 1990 


\section{MASTER OF COMMUNITY PLANNING \\ RESEARCH PROJECT \\ OF \\ ANNE CUNNINGHAM}

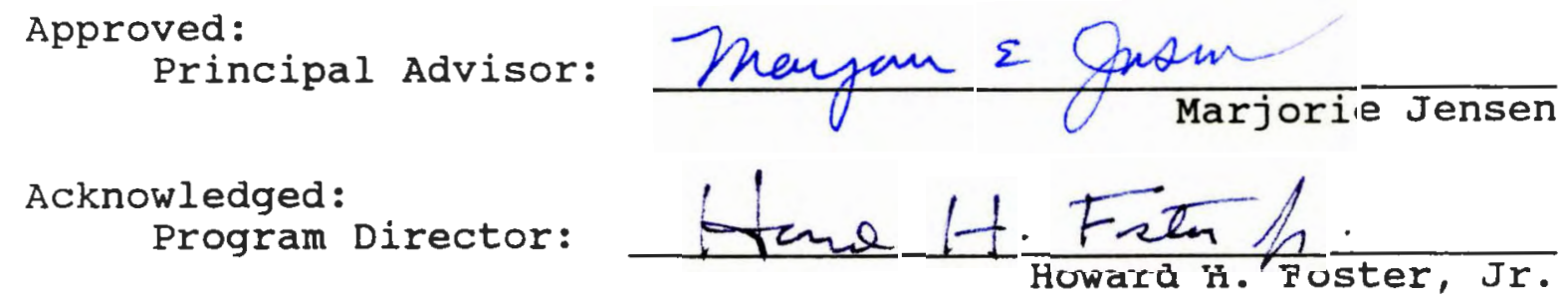




\begin{abstract}
The purpose of this Masters Research Project is to determine the extent of need for subsidized housing among the physically handicapped and sight and hearing impaired populations of Providence, Rhode Island, with a view to making recommendations for improvements in both the supply and quality of residential units provided for these people by the Providence Housing Authority. In addition, an examination is made of the minimum requirements mandated by the U.S. Department of Housing and Urban Development (Section 504, Title $V$ of the Rehabilitation Act of 1973, as amended) for upgrades to the PHA housing stock, and an analysis is conducted of the necessary improvements to be made at each of the Authority's developments during the early 1990's.
\end{abstract}


TABLE OF CONTENTS

Page

Ảbstract

Table of Contents ii

List of Tables iv

List of Figures v v

CHAPTER ONE INTRODUCTION: STATEMENT OF ISSUES AND PROBLEMS

1.1 Purpose of the study

1.2 Background to Current Housing Problems 2

1.3 Overview of the PHA: Organizational

structure and Mission

1.4 Organization of the study 5

CHAPTER TWO A REVIEW OF IITERATURE 11

2.1 Legislative Framework 11

2.2 National Housing Trends 12

2.3 Disabled Population 17

2.4 Housing Production in Providence 20

2.5 Housing Affordability in Providence 25

2.6 Federal Legislation 28

2.7 Handicapped/Housing Legislation in RI 33

2.8 Housing Initiatives 34

$\begin{array}{lll}\text { CHAPTER THRE } & 38\end{array}$

3.1 Department of Housing and Urban Development Requirements 38

3.2 PHA Inventory of Wheelchair and Hearing/

Sight Impaired Accessible Units
3.3 Providence Housing Authority Disabled Population

3.4 Units Needed to House Disabled Residents and Applicants

3.5 Social Services Provided by the PHA 51

3.6 Citywide Inventory of Wheelchair Accessible Units

3.7 Citywide Estimate of Disabled Population 57

3.8 Resident and Community Input 60

3.9 Physical Accessibility and HUD Regulations 66

3.10 Summary

68 


\section{TABLE OF CONTENTS/Continued}

Page

CHAPTER FOUR RECOMMENDATIONS

4.1 Introduction

72

4.2 The Plan

72

4.3 Conclusion

80

Bibliography

82

APPENDICES

Appendix A Subpart C-Program Accessibility of the Federal Register at FR 20216-20254. HUD final rule on Section 504

Appendix B PHA Handicap Verification Form

Appendix $C$ Listing of HUD Multi-family

Housing: Handicap Listing

Appendix D Methodology for Estimating the

Disabled Population of the City of Providence 


\section{LIST OF TABLES}

Page

Table 1 Disability Comparison for Providence, 1980

Table 2 Percentage of Providence Population That is Elderly

Table 3 Construction Trends by Ownership Category

Table 4 Percentage Change in Median Selling Price of Single Family Homes in Providence

Table 5 Providence Residential Market, 1979-1989, Comparison of Rents, Household Incomes and Affordability

Table 6 Federal Requirements and Current/Funded Units

Table 7 Current and Funded Wheelchair Accessible Units, by PHA Development

Table 8 SSI Recipients, by PHA Development

Table 9 Discrepancy in Handicapped Units Needed and Provided

Table 10 Inventory of Social Services Available to PHA Residents

Table 11 Providence Handicapped Population for 1980,1989 and 1994

Table 12 Wheelchair Accessibility to Non-dwelling Unit Areas, by Development 


\section{LIST OF FIGURES}

Page

Figure 1 organizational structure of the PHA

Figure 2 Providence Neighborhoods with PHA Developments

Figure 3 Providence Residential Construction

Figure 4 HUD Subsidized Wheelchair Accessible Units in Providence, by Census Tract

Figure 5 HUD Subsidized wheelchair Accessible Units in Providence, by Neighborhood 
CHAPTER ONE

INTRODUCTION: STATEMENT OF ISSUES AND PROBLEMS

\subsection{Purpose of the study}

The purpose of this master's project is to assess the need for affordable and accessible housing for physically disabled people in the City of Providence in order to develop guidelines, which will assist the Providence Housing Authority in providing the number and type of housing units that will best serve this segment of the population.

Physically disabled citizens, long an almost silent minority, are finding a voice through federal legislation to demand recognition, understanding of their special needs, and accommodation of government to those needs.

The United States Department of Housing and Urban Development (HUD), in response to section 504 of Title $V$ of the Rehabilitation Act of 1973, as amended, is requiring all public housing authorities to increase the number of handicapped accessible housing units available, as well as to ensure the total accessibility of their housing developments. On June 2, 1988, HUD published the subject final rule in the Federal Register at FR 20216-20254. This final rule implements section 504. Part 8-Nondiscrimination Based on Handicap in Federally Assisted Programs and Activities of the Department of Housing and Urban Development, Subpart C-Program Accessibility contains the requirements concerning program accessibility for public 
housing authorities (see APPENDIX A).

Briefly, these requirements are: that a minimum of 5 percent of public housing units be wheelchair accessible, and that 2 percent of all public housing units be accessible to either hearing or sight impaired people.

This study documents existing conditions and trends relative to the provision of housing for income eligible, physically disabled people in Providence. This includes changes in the housing market, numbers of units offered both by the Authority and other subsidized organizations, the demographics of the physically disabled within the PHA and citywide, and services available to this group.

\subsection{Background to current Housing Problems}

During the mid-1980's the cost of housing escalated to a high point between 1985 and 1986 when a statewide increase of 31 percent for a single-family home substantially impacted the housing market in Rhode Island. For this same period that was a concomitant rise in residential rents. In a study carried out by winsor Associates (1990) for the City of Providence, it was determined that during the 1980's, in every neighborhood in the city, except one, the rents more than doubled. Accompanying this increase in rents was a rise in the percentage of income used for rent, making it even more difficult for people on fixed incomes to pay for housing . 
A significant proportion of physically disabled people fall into this fixed income category. In a study by The Governor's Committee on Employment of the Handicapped (1980) it was determined that the disabled population of Rhode Island was older, less likely to be employed, had less education, and was more likely to be receiving assistance than the general population. Moreover, many of these people require additional accessories and adaptations to their living space, making their housing even more costly than the general public.

The number of physically disabled people is increasing. With the continued refinement of technical skills, now babies born after four months gestation can be saved, where as in the past they would not have survived. Modern medicine also allows people to live longer, adding an entirely new demographic category to our language; the frail elderly. All these people need appropriate housing, and many fall under the physically disabled umbrella. If housing for the physically disabled is to be provided it is necessary to understand who and how many fall within the category, and how best to provide for those who cannot afford satisfactory housing on their own incomes. The Providence Housing Authority exists to provide safe, decent, and affordable housing for the low income people living in the city of Providence, and is working to expand its services for the physically disabled. 


\subsection{Overview of the PHA: Organizational structure/Mission}

In order to provide a context for understanding the Providence Housing Authority's ability to respond to the need for housing for the disabled, an overview of the agency's mission and organizational structure is provided.

The Mission statement for the PHA states first, "To provide decent, safe and sanitary housing and the highest level of service to responsible low income families and individuals" and second, "To create an environment which enables residents to live responsibly and with dignity and to support them in their efforts to achieve selfsufficiency."

To carry out this mission, the Providence Housing Authority was created in 1939 in accordance with the provisions of Chapter 45-25-7 of the General Laws of Rhode Island.

The PHA is a "body corporate and politic" governed by an eleven-member Board of Commissioners. Nine of the Commissioners are appointed by the Mayor of Providence, with three of his or her appointees chosen from among the residents of PHA developments and two elected by the city council from among its members.

The organizational structure of the PHA requires that the Executive Director report to the Board of Commissioners. He or she is responsible for implementing all PHA policies. The six departments within the PHA are Housing Management, Planning and Special Services, Finance and Accounting, 
Modernization and Development, Maintenance and Rental Housing (See FIGURE 1).

The PHA owns and manages 2,630 units of low income public housing located in thirteen developments and various scattered sites. Built in 1942, Chad Brown is the oldest of the public housing sites constructed in Providence (See FIGURE 2). Chad Brown, Admiral Terrace and sunset Village have recently undergone complete renovation. Hartford Park and Manton Heights modernization programs are under way, and Codding Court and Dexter Manor I modernization programs are in the planning stages.

In addition, the Authority administers section 8 Certificates and Vouchers, as well as the Section 8 Moderate Rehabilitation Program which is carried out in conjunction with the city. This amounts to a total of 1,608 subsidized units in addition to the PHA-owned properties.

\subsection{Organization of the study}

The principal questions to be addressed in this study are:

- What is the demand for handicapped accessible housing in Providence?

- What is the supply of subsidized, handicapped accessible housing units in Providence?

- What are the perceived needs of this population?

- What are the most appropriate recommendations for the Providence Housing Authority's handicapped 
FIGURE 1

Providence Housing Authority Table of Organization

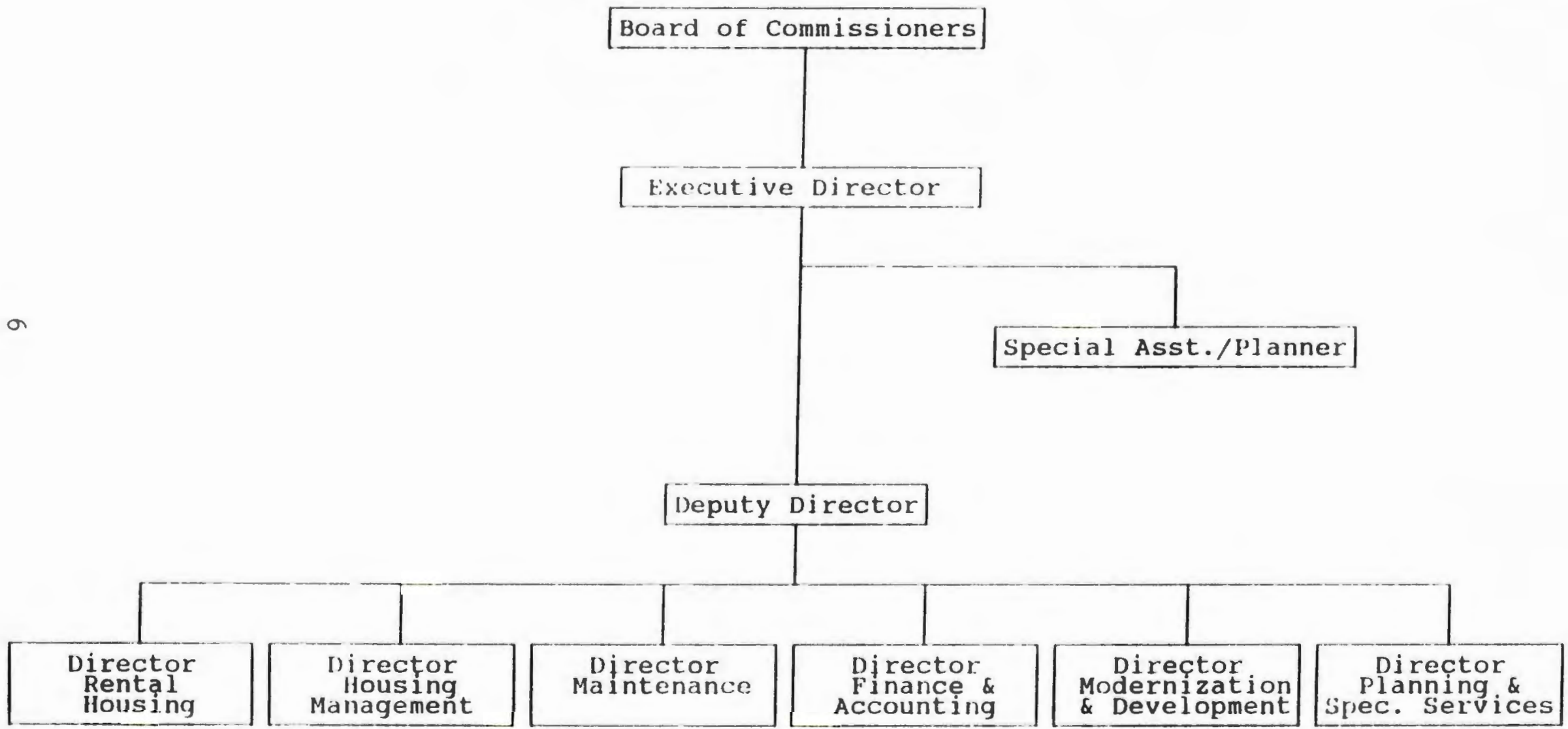




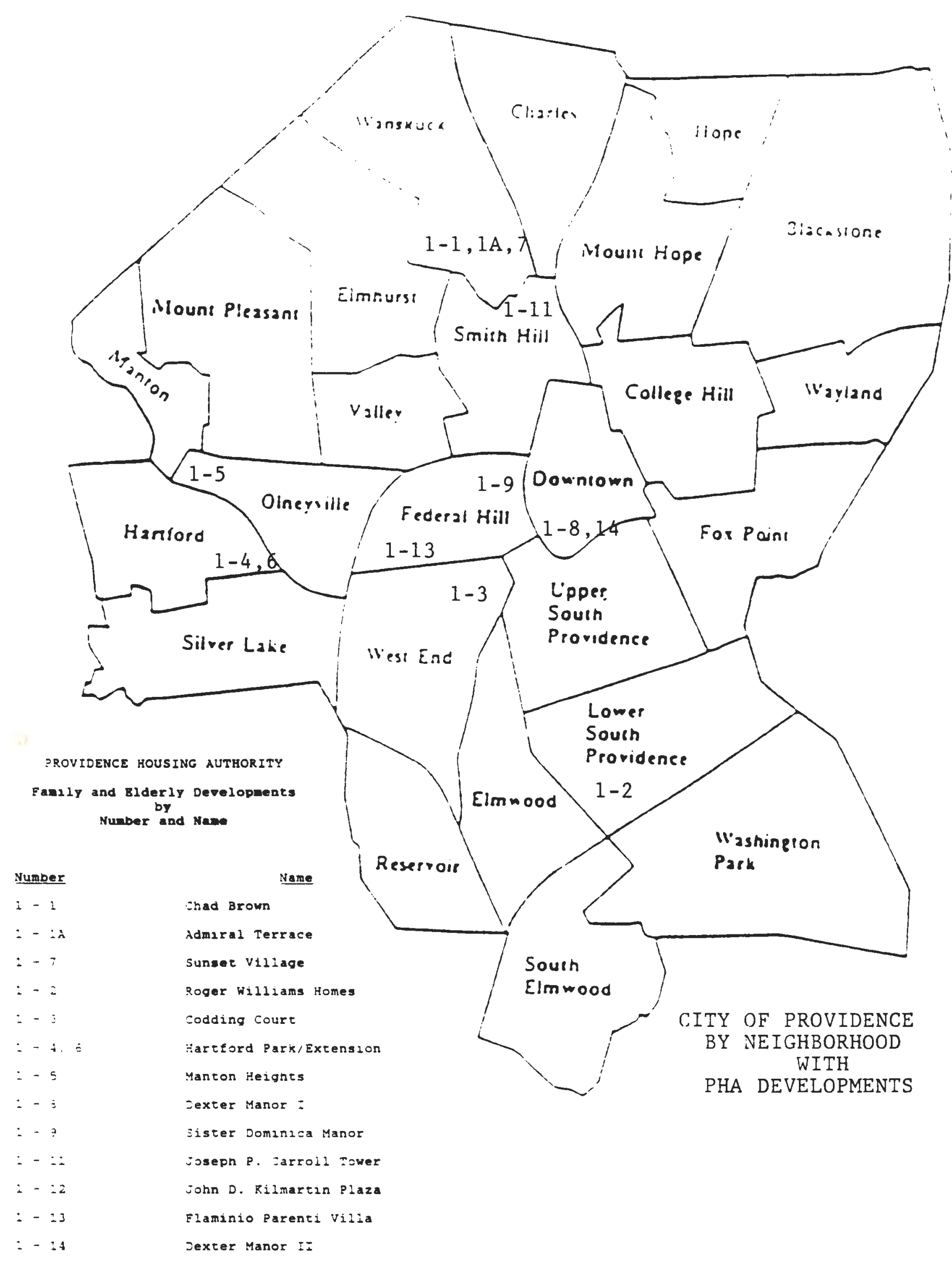


accessibility program?

In addition to this introductory chapter, this master's research project is organized into three chapters:

\section{- Chapter Two: A Review of Literature}

The purpose of the literature review is to situate the discussion of housing problems and policies for the physically disabled in Providence within a more theoretical and national context. The literature review focuses on eight key elements of the research:

1. Trends in national housing, including data on home ownership, the residential rental sector and demographic shifts;

2. Decreases in federal funding of public housing initiatives since 1980 ;

3. Characteristics of the disabled population in Rhode Island and in Providence;

4. The type, rate and characteristics of housing production in Providence during the 1980's;

5. The issue of housing affordability in Rhode Island's capital city;

6. Federal legislation specifically relating to the issue of disabled housing provision in the public sector;

7. State legislation which has -- or will -- impact the provision of public housing units for the disabled; and

8. Housing initiatives which emerge from the researcher's examination of the literature. 


\section{- Chapter Three: Presentation of Findings}

This section of the research project includes:

1. The study of the needs of the disabled population of Providence as well as the resident disabled population of the Providence Housing Authority; and

2. A discussion of the Providence Housing Authority's planned response to the identified needs of disabled people.

Chapter Three is divided into six sections, as follows:

1. Define and inventory the handicapped accessible units available in the PHA;

2. Identify physically disabled residents in and applicants to the PHA, the type of units they live in and develop a list of their needs;

3. Inventory social services available to physically disabled PHA residents and identify the services needed;

4. Inventory wheelchair accessible units available in the City of Providence to determine the supply of such units ;

5. Estimate the number of income eligible, physically disabled people citywide to define the demand on the existing housing stock; and

6. Determine for each PHA development the physical obstacles that have been identified by HUD, through interviews with residents, PHA staff, and other service providers. 
7. Summarize the findings of the analysis developed to determine the extent of need for handicapped accessible units.

\section{- Chapter Four: Recommendations}

The practical outcome of this master's research project is a set of very specific proposals for each of the housing developments managed and operated by the Providence Housing Authority, including the necessary actions the PHA must take in order to bring these units into compliance with section 504, Title V. Information is provided, for each development, on the following areas for action:

1. Number of units in each development;

2. The number of units in each public housing development which are currently wheelchair and hearing/sight impaired accessible;

3. The percentage of total units in each development which must be wheelchair and hearing/sight impaired accessible under section 504, Title V;

4. The site and architectural obstacles to achieving the HUD requirements; and

5. Action steps that the PHA should take to bring each development into compliance with the regulations. 
CHAPTER TWO

A REVIEW OF LITERATURE

\section{1 Legislative Framework}

In July of 1949 the 81st Congress passed, and President Harry S. Truman signed, a major housing act that declared as an objective of public policy "the realization as soon as feasible of the goal of a decent home and a suitable living environment for every American family." (Public Law 171, 63 Stat. 413 (1949)) Still, 42 years later, we continue searching for solutions while the number of needy elderly, poor and disabled increases at a disturbing rate.

There is, of course, a variety of reasons why we are not yet able to catch up with ourselves. Many of the housing trends of the 1980's have illuminated why affordability and availability seem to recede before us even as governments continue to finance and subsidize housing for low and moderate income people.

Although the focus of this paper is on the disabled population in providence, it is nevertheless extremely difficult to separate the disabled from the elderly and the poor. First, the disabled are to a great extent poor and to a great extent elderly. Second, there is very little information solely addressing disabled people. It is only recently that through legislation and education the disabled are becoming a visible and articulate group. Third, it is necessary to understand some basic background 
information about national housing trends currently in motion because virtually all housing issues are related.

\subsection{National Housing Trends}

- Decrease in Home Ownership

A decline in home ownership since 1980 has eroded that most precious of American dreams - home ownership. Between 1940 and 1980, the percentage of those Americans owning their own homes grew from 44 percent to 65 percent. From 1980 to 1986 the overall drop was 1.8 percent nationally, with a 6 percent drop for the 30-34 age group and an average of a 4 percent drop for the 35-44 age group (Schwartz and Hoffman 1988).

\section{- Increase in cost of Housing}

During the 1980's the cost of housing has escalated. The National Association of Home Builders reports that in 1977 the median cost of a new house was $\$ 48,000$, and for an existing house was $\$ 42,900$. By 1986 the cost had risen to $\$ 92,000$ for a new house and $\$ 80,300$ for an existing home. Steinleib and Hughes (1987) report that the percentage change from 1970 to 1985, for existing single-family homes sold was 253.2 percent for the Northeast, 192.5 percent for the midwest, 235.1 percent for the South and 291.8 percent for the West.

Steinleib and Hughes further explain that, "While this rate of increase (259.4 percent nationally) was far in excess of the overall pace of inflation as measured by the 
CPI (177 percent), the total impact on the house purchaser was further magnified by the escalator of rising mortgage rates." (p.143).

Renters had no easier a time, as the percentage of families, nationally, with rent consuming above one-quarter of their income increased from 40 percent in 1974 to 60 percent in 1983. (Schwartz and Hoffman 1988) The increased costs in both owner-occupied and rental housing signify a decline in the available housing stock affordable to the low and moderate income people as well as a growth in the number of people needing affordable housing. This gap formed by the decrease in supply and an increase in demand for affordable housing is the area addressed by public housing.

\section{- Increase in Homeless Population}

During the 1980's there was an astonishing increase in the number of homeless people, with the most dramatic aspect of homelessness being the sharp increase in the number of families without permanent shelter. In 1984 HUD reported that 21 percent of the homeless were families. In 1986, the U.S.Conference of Mayors found the number of families had increased 31 percent over the past two years. In 1987 a study by the Partnership for the Homeless of New York found a majority of cities responding to them reported over 30 percent of the homeless were families.

\section{- Decrease in Federal Funding for Housing}

A fourth trend affecting housing is the decrease in federal spending during the 1980's. Expenditures on housing 
programs were cut more deeply during this time than in any other area of federal spending. Total budget authority for HUD diminished by 57 percent from 1980 to 1987 , from $\$ 35.7$ billion to $\$ 15.2$ billion - from 7 percent of the federal budget in 1978 to 1 percent in 1987 (Schwartz and Hoffman 1988).

Across the nation, these cuts were particularly severe in the area of new housing construction. In the 1981 budget 33,242 new, HUD assisted public housing units were funded; in $1984,5,212$ were funded, and in 1987, 0 were proposed. The Providence Housing Authority was very fortunate in receiving appropriations in 1987 for 240 replacement (not additional) units to be new construction. No additional, newly constructed units have been added to the PHA stock since 1983 when ninety-one units of elderly units were built. The last family units to be constructed were at Manton Heights, occupied in 1954 (see FIGURE 2).

Housing vouchers, seen as an alternative to new construction, were first funded in 1983. Since that time the percentage of total HUD-assisted housing that vouchers represent for the entire country has risen from 39 percent in 1985 to a proposed 96 percent in 1988. Concomitantly, the percentage of new construction (not rehab) has fallen from 56 percent in 1982 to a proposed 4 percent in 1988 (U.S. Department of Housing and Urban Development, 19811988).

Most affected by this decline in housing funds are the 
elderly, handicapped persons, and low and moderate income families who often depend on rental assistance or subsidized public housing for their homes. These basic federal programs were cut by more than 70 percent in the $1980^{\prime} \mathrm{s}$.

- Demographic Trends

Finally, there are three national demographic trends which have predicted a shortage in the available housing for low and moderate income people in the 1990's. First, there is a substantial increase in the number of households in this country. The size of a household in 1940 was 3.67 persons, in 1975 it was 2.94 , and in 1985 it was 2.69 . (U.S.Bureau of the Census 1985a) This statistic covers all household types with the exception of two or more unrelated adult households, and holds true for every region and metropolitan area, for both owned and rented households (Hughes and Sternlieb 1987). This is due largely to single, female-headed households and people living alone, many of whom are elderly and/or disabled, all population groups that tend to have lower incomes and live in public housing.

The second demographic trend is the increase in longevity which has produced a new category of older people, the frail elderly. "The absolute annual growth of those 65 years of age and older in the 1980's was (also) less than that of the 1970's. But as the demographic profile of 1985 for persons living alone is reviewed, the potential burden of support and future shelter requirements is made evident by the nearly 11 million persons living by themselves who 
were over the age of 55." (Hughes and Steinleib 1987) Many of the elderly, already residing in PHA housing will "age in place", eventually requiring a high level of care. Housing authorities around the country are working to establish programs that will allow these elderly to remain in public housing while being cared for in a humane and effective manner.

Third, the baby boomers born in the 1950's are reaching the 30-45 year age group. This is the group that has historically purchased their first home. As their purchasing power decreases due to the rise in the cost of housing, their presence in the housing market, both owneroccupied and rental, will place an additional strain the on the supply of available, affordable housing in the 1990's.

All of these national trends point to a tighter housing market in the 1990's, particularly for the lower income people, the elderly and the disabled. The remainder of this chapter focuses on the problem of meeting the "goal of a decent home" for a specific group---the low-income, physically disabled people in the city of Providence. A study of the Rhode Island and Providence disabled population and an overview of the Providence housing market will be followed by a summary of federal and state legislation which affects housing for the disabled. In addition, recent proposals for new affordable housing initiatives by state, local and federal government are reviewed. 


\subsection{Disabled Population}

The 1980 United States Census reported 36 million disabled American citizens. This figure was ascertained through answers to only two inquiries on the survey: first, the noninstitutionalized people with a work disability and those not in the work force, and second, those persons with a public transportation disability and those not in the work force (U.S. Bureau of the Census 1980) .

\section{- The 1980 Rhode Island Census of Disabled People}

Prior to the 1980 Census, on learning of the minimal definitive information that would be produced about the disabled population nationwide, the Rhode Island Governor's Committee on Employment of the Handicapped was funded to carry out a detailed survey of the disabled population in the state.

\section{The 1980 Rhode Island Census of Disabled People found} that 17.6 percent of the population surveyed was disabled. Using the Statewide Planning 1980 estimate of 944,700 residents in the state, the disabled population was estimated to be 166,200 statewide.

The Governor's Census also estimated the number of disabled people in all the state municipalities. It was estimated that 21.8 percent of the Providence population was disabled, 4.2 percent higher than the state percentage. Again, using statewide Planning figures which estimated the 1980 Providence population at 154,300 ; the number of 
disabled people in Providence was estimated to be 33,637.

This total included all disabled people, as the Governor's census used the definition contained within the Rehabilitation Act of 1973, as amended, which reads, a "handicapped individual is any person who has a physical or mental impairment which substantially limits one or more of such person's major life activities." Therefore, the number of disabled people in providence (1980) of 33,637 covers a broad spectrum of disability types as well as a wide range of degree of disability.

There are three basic groups of disabilities enumerated in the Governor's Census: health, physical and mental. For each disability group, the number and the percentage for Providence are listed below in TABLE 1. Again, this does not mean that 18,097 physically disabled people in Providence were confined to wheelchairs. It does mean that some are, some will be in the future, while others may never be. At this time there is no accurate means of predicting the above percentages.

TABLE 1

DISABILITY COMPARISON FOR PROVIDENCE, 1980

\begin{tabular}{|c|c|c|}
\hline Type of Disability & \# Prov. Disabled & Prov. Disabled \\
\hline \hline Physical Disability & 18.097 & 53.8 \\
\hline Mental Disability & 11,504 & 34.28 \\
\hline Tealth Disability & 4.036 & 12.08 \\
\hline TOTAL & 33.637 & 100 \\
\hline
\end{tabular}

Source: 1980 Rhode Island Census of Disabled Persons 
Among other demographic characteristics stated in the Governor's census are:

- 60 percent of the disabled population was over the age of 55 as compared with 24 percent of the general population:

- 42 percent of the disabled population was employed as compared with 59 percent of the general population; and

- Almost 75 percent of the disabled population was receiving income from social security, public assistance or pensions.

Since this study was completed there have been no other comprehensive studies of the disabled population in Rhode Island. This has led to a serious deficit of information regarding this population making planning for this group difficult, and has allowed their particular problems to be ignored.

In 1980, the elderly population comprised a large segment of the disabled population. The elderly, not restricted to the disabled, is also a sizable and growing segment of the general population. See TABLE 2 .

TABLE 2

PERCENTAGE OF PROVIDENCE POPULATION THAT IS ELDERLY

\begin{tabular}{|c|c|c|c|}
\hline Age Cohort & 1980 Census & 1989 Estimate & 1994 Projection \\
\hline $55+$ Years & 9.88 & 10.98 & 11.18 \\
\hline $75+$ Years & 4.48 & 5.68 & 5.28 \\
\hline
\end{tabular}

Source: D\&B Donnelley Demographics, 1988 
The percentage increase in the 75+ age group from 1980 to 1994 is almost $2(1.8)$ percent. This is .5 percent higher than the $65+$ group. As more people live longer, well into their seventies and eighties, the ranks of the disabled will swell with the frail elderly population.

Concurrently, with the continued refinement of technical skills within the field of medicine, more premature babies are surviving. Where once a four-month fetus born would certainly die, now they can survive; many to be faced with severe disabilities. These children will also need specialized care and housing.

While definitive current figures on the disabled population are virtually unavailable, we can anecdotally and through projections show that the disabled population is a substantial one (refer to Chapter Three). More statistical information will have to be compiled on this group in the future, particularly as more funding becomes available through federal and state legislation.

\subsection{Housing Production in Providence}

From January 1980 to June 1989, Winsor Associates (1990) reports a total of 1,078 residential building permits for new housing starts, representing 2,543 individual housing units, were issued by the city of Providence. Almost half of these permits were issued in 1987 and 1988, in response to the housing market "boom" experienced in 1985-1987. In 1989, the number of permits decreased, 
bringing new construction back in line with the earlyeighties at around 300 housing starts per year. FIGLRE 3 shows the precipitous increase and eventual decrease of residential construction in the 1980's

FIGURE 3

PROVIDENCE RESIDENTIAL CONSTRUCTION

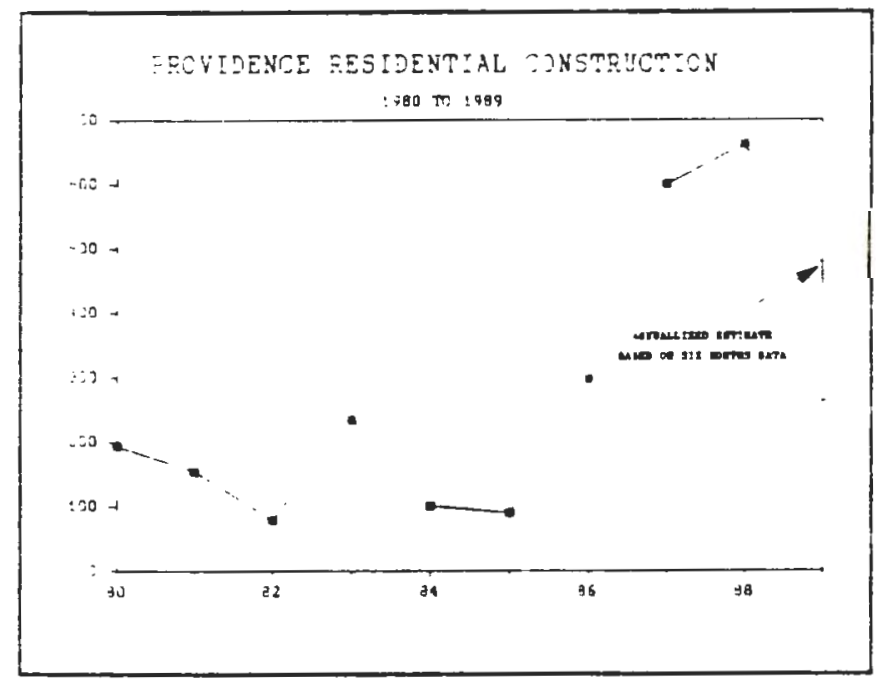

Source: Winsor Associates, 1990

As to the ownership of this new construction, winsor Associates (1990) looked at five categories: private, commercial, non-profit, public and institutional. As TABLE 3 shows, the non-profit sector representing those housing units affordable to low and moderate income people, comprised only 2.7 percent (a total of thirty) of the building permits authorized from January 1980 to June 1989. 
TABLE 3

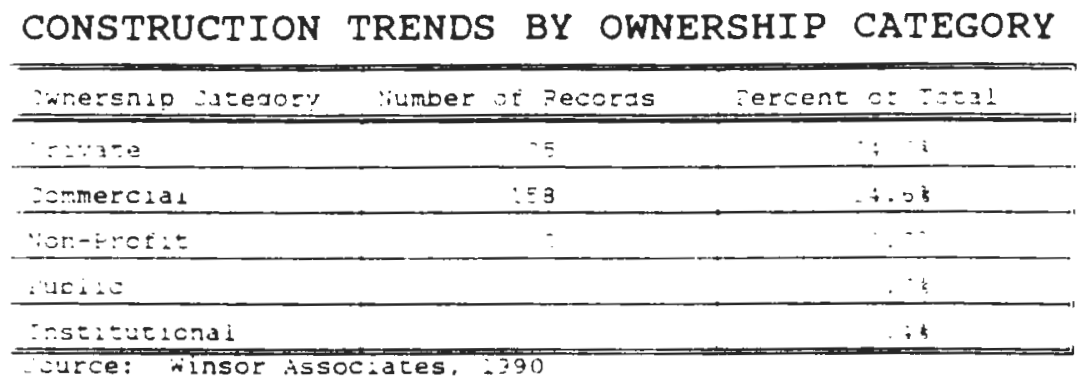

\section{- Public sources of Funding}

The City of Providence supports the development of housing for low and moderate income people through several channels. The Community Development Block Grant (CDBG) is a yearly HUD grant to entitlement cities of funds covering all HUD sponsored programs. The size of the grant is determined by percentage growth in population, percentage of persons below poverty level, and the number of housing units built before 1940. The funds are used at the discretion of city officials, and may be used for programs other than housing such as economic development, administration and public services.

In a study by the A. Alfred Taubman Center for Public Policy and American Institutions, at Brown University, (1988) it is stated that: "Overall, the 81 cities included in our national sample, earmarked nearly half of their 1987 CDBG funds for housing programs; in Providence, less than one-fifth of the City's CDBG entitlement was used for housing activities." (p.23) In actuality, only $\$ 400,000$ or 6.88 percent of the city's $\$ 5.9$ million grant in 1987 went directly to the rehabilitation of housing. 
Two other potential funding sources for low and moderate income housing are the Urban Development Action Grant (UDAG) and the Housing Development Action Grant (HODAG). The UDAG is an economic development program, the payback from which is to be used to support affordable housing and community development projects. The HODAG is direct housing funds that require 20 percent of the units be available to low and moderate income families for 20 years. The Taubman study reports that 26 units of affordable housing ( $\$ 18.0$ million funded) have been supplied through the UDAG program (from 1977-1987), and 28 units have been provided ( $\$ 3.0$ million funded) through the HODAG program (from 1984-1987).

The final housing program sponsored by the city is the Rental Rehabilitation program in which up to $\$ 5000$ per housing unit will be matched by the city for rehabilitation of rental units. The initial tenants, after the rehabilitation is completed are to be low income. This is encouraged by supplying the first tenants with section 8 Vouchers or Certificates. $\$ 1.5$ million in program funds have leveraged over $\$ 2.0$ million in private funds for the rehabilitation of approximately 450 units in 119 buildings since 1984. Therefore, the Rental Rehabilitation program has proved to be more efficient at producing homes for the poor than either the UDAG or HODAG programs.

State financed housing programs that affect the low, moderate and middle income population in Providence are 
administered through the Rhode Island Housing and Mortgage Finance Corporation (Rhode Island Housing), an entity established in 1973 by the state legislature to creatively address the unmet housing needs of lower-income state residents. The federal government sets the definitions for levels of income. Low income is 50 percent and below the median family income for the area; moderate income in 51 80 percent of the median area family income; and anything above 80 percent would be middle income and above.

Through the sale of tax-exempt notes and bonds, as well as direct funding from the state, Rhode Island Housing provides mortgage assistance, repair loans, loans for nonprofit and for-profit housing construction, and emergency housing and shelter grants.

The Taubman report is critical of the high proportion of Rhode Island Housing funds spent on mortgages for middle income people as contrasted with the level of funding stipulated for housing production for low and moderate income people. Using figures from the Taubman report, from 1986 to 1988 , over $\$ 95.8$ million dollars have been available for mortgages and only $\$ 10.0$ million have been available for housing development. Furthermore, the report states that of the $\$ 10.0$ million earmarked for housing development, only $\$ 5.0$ million has been committed.

Neither the city nor the state has been successful in stimulating the production of low and moderate income housing. The Providence Housing Authority is well aware of 
the dearth of affordable housing in Providence because currently there are well over 2000 people and families on the waiting list for subsidized housing. This lack of availability coupled with the tightening of federal funds does not auger well for affordable housing.

\subsection{Housing Affordability in Providence}

In New England, the housing market "boom" that swept over this part of the country in the mid-1980's dramatically impacted housing affordability. During this time Providence participated fully, drawing investors attracted by the relatively low real estate prices (as compared to Massachusetts and Connecticut) from all over New England.

Winsor Associates (1990) documented real estate trends affecting the affordability and availability of housing in the 1980's. The study showed that although the cost of single-family homes rose steadily in the early 80 's, a high point was reached in 1986 when the median cost rose 31 percent statewide. In Providence, as indicated in TABLE 4, there was a phenomenal increase of over 88 percent in the median cost of a single family house on the East Side (which includes the neighborhoods of Blackstone, College Hill, Wayland, Hope, Mount Hope and Fox Point) (see Figure 2) from 1985 to 1986; as well as the less sensational but nevertheless major increases for the rest of the Providence neighborhoods from 1985 to 1987. 


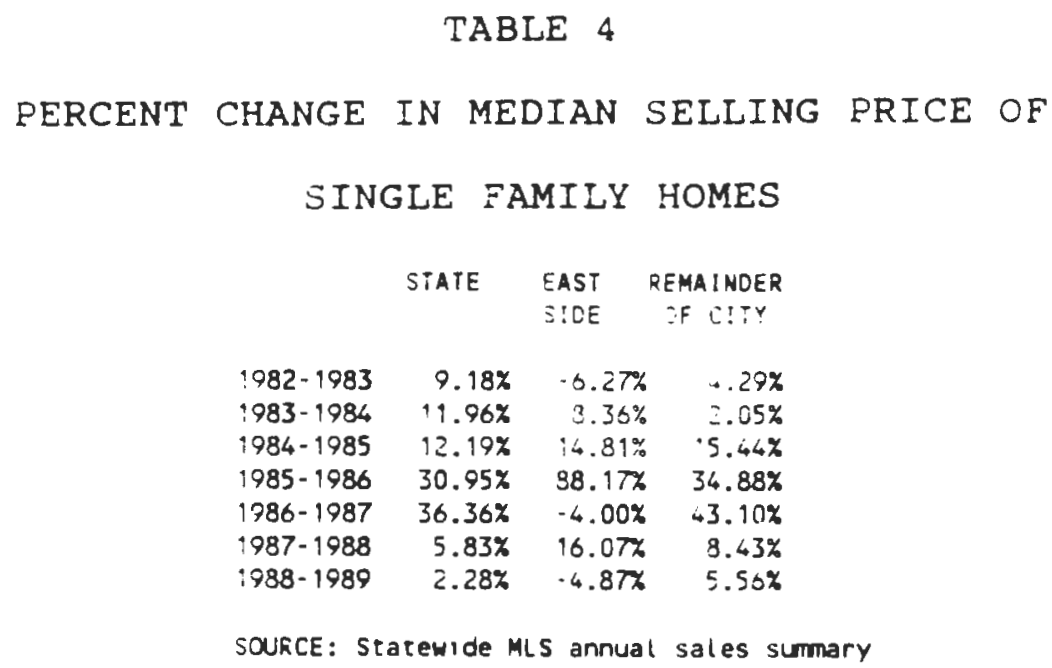

overall, the increase in the median cost of a single family home for the remainder of the city, which was 171 percent, was greater than the increase in the median cost of a single family home on the East side where houses were originally higher priced. This suggests that the traditionally less expensive neighborhoods were more heavily impacted by the increase in real estate costs than were the affluent neighborhoods.

In the rental housing market, costs kept pace with the housing sales findings. In TABLE 5, rents for 1979 and 1989 are compared. 
TABLE 5

PROVIDENCE RESIDENTIAL MARKET, 1979-1989

COMPARISON OF RENTS, HOUSEHOLD INCOMES AND AFFORDABILITY

\begin{tabular}{|c|c|c|c|c|c|c|c|c|c|c|}
\hline & & & & & .S. ¿ENSUS & WINSOR & & WINSOR & WINSOR & EACI \\
\hline & & & & PERCENT & MED IAN & MED I AN & CACI MED & AFFORD - & AFFORD - & AF FORD - \\
\hline & & MED IAN & MED IAN & CHANGE & HOUSEHOLO & HOUSEHOLD & HOUSEHOLD & ABILITY & ABILITY & ABILITY \\
\hline & & RENT & RENT & (RENTS) & INCONE & I ACOME & I NCOME & I MDEX & INDEX & I HDEX \\
\hline$\exists$ & NE I GHBORHOOO & 1979 & 1989 & 197 & 1979 & 1989 & 1989 & 1979 & 1989 & 1989 \\
\hline 1 & BLACKSTONE & 54.0 & .00 & 6 & 847.00 & 1 &, 15 & $11.4 \%$ & 14 & $18.9 x$ \\
\hline 2 & ARLES & & & & 170.00 & & $\$ 21,046.00$ & $12.1 \%$ & $19.1 x$ & $24.2 x$ \\
\hline & COLLEGE HILL & .00 & 650.00 & & $12,453.00$ & $\$ 27,371.69$ & $\$ 20.633 .00$ & $23.2 \%$ & $28.5 x$ & $37.8 \%$ \\
\hline$\dot{4}$ & DOWN TOWN & 197.00 & 519.00 & $3.5 \%$ & $\$ 7,954.00$ & $\$ 17,482.89$ & $\$ 13,184.00$ & 29.77 & $35.6 \%$ & $47.2 x$ \\
\hline 5 & ELMHURST & $\$ 169.00$ & 450.00 & $166.3 \%$ & $\$ 18,029.00$ & $539,627.74$ & $\$ 30,452.00$ & $11.2 x$ & $13.6 \%$ & $17.7 x$ \\
\hline & ELMLOOO & & & & $58,672.00$ & 061.06 & $\$ 16,108.00$ & $20.8 \%$ & $24.2 \%$ & $28.7 \pi$ \\
\hline 7 & FEDERAL HILL & $\$ 99.00$ & 409.00 & & $\$ 7,265.00$ & 968.47 & $\$ 12,444.00$ & $16.4 x$ & $30.7 x$ & $39.4 \%$ \\
\hline 8 & FOX POINT & $\$ 152.00$ & 550.00 & $.8 x$ & $\$ 12,867.00$ & 281.67 & $\$ 22,935.00$ & $14.2 x$ & $3.3 \%$ & $28.8 \%$ \\
\hline द & HARTFORD & 0 & 500.00 & $.2 x$ & $\$ 9,284.00$ & 406.23 & $\$ 16$, & $13.6 \%$ & $29.4 \%$ & $37.5 \%$ \\
\hline$: 0$ & HOPE & & .00 & $.5 x$ & $\$ 16,484.00$ & & s29. & $13.9 \%$ & $5.4 x$ & $18.6 \%$ \\
\hline & LOUER S PROY & .00 & .00 & $.9 x$ & $\$ 7,450.00$ & 10 & $\$ 13$, & $18.4 \%$ & $3 \%$ & $35.9 x$ \\
\hline 2 & MANTON & 0 & .00 & $.2 x$ & $\$ 15,714.00$ & 37 & $\$ 2$ & $.5 \%$ & $.3 x$ & $17.1 \%$ \\
\hline 3 & MOUNT HOPE & & 00 & $.6 x$ & $\$ 9,967.00$ & 7.47 & $\$ 20$, & $19.4 x$ & $.4 x$ & $29.9 \%$ \\
\hline 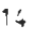 & EASANT & & 00 & & $\$ 14,572.00$ & 9.25 & 524, & $2.4 \%$ & $.2 \%$ & $22.1 \%$ \\
\hline$: 5$ & OLNEYVILLE & & & $.3 x$ & $\$ 9,132.00$ & 072.14 & 514, & $13.5 \%$ & $.9 x$ & $32.0 \%$ \\
\hline 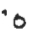 & VOIR & & & & $\$ 14,438.00$ & 734.72 & $\$ 24$. & $3.3 \%$ & $.0 x$ & $23.7 x$ \\
\hline 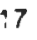 & SILVER LAKE & & & & s11, & & $\$ 20$, & 6.08 & 0.87 & $26.3 x$ \\
\hline${ }^{4} 8$ & SMITH HILL & & & & $\$ 8,383.00$ &, 425.83 & $\$ 14$, & $5 \%$ & $6.4 x$ & $31.6 x$ \\
\hline 19 & S ELMWOOO & & & & $\$ 14,958.00$ & $2,877.68$ & 516,9 & $13.7 \%$ & $.0 x$ & $29.2 x$ \\
\hline 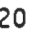 & UPPER S PROV & & & & $\$ 5,821.00$ & $\$ 12,794.56$ & $\$ 10$, & $24.9 x$ & $.2 x$ & $51.6 \%$ \\
\hline & VALLEY & & & & $\$ 11.077 .00$ &, 34 & $\$ 18$ & $14.7 x$ & $2 \%$ & $26.5 \%$ \\
\hline & WANSKUCK & & & & oo & 56 & $\$ 19$ & $8 x$ & $5 \%$ & $30.6 \%$ \\
\hline & WASHINGTON PK & & & & $12,822.00$ & 18 & & $.5 \%$ & $2 \%$ & $24.6 x$ \\
\hline 2 & WAYLAND & & & & 16,556 & 9 & & $6 x$ & & $24.4 \%$ \\
\hline & WEST END & & 425.00 & & jo & 7 & & $.3 x$ & $.2 x$ & 37.77 \\
\hline & & & & & & & & & & \\
\hline & & & & & & & & $x^{2}$ & • & $26.5 \%$ \\
\hline
\end{tabular}

SOURCES: U.S. Bureau of the Census, 1980; U.S. Bureau of Economic Analysis, 1989; R.1. Department of Emoloyment Security, 1989; Providence Journal Classifieds (5.714), June-August, 1989; CACI, Inc., Fairfax, VA, Jemograpnic and Income forecast Report

VOTES: Winsor Associates 1989 income data for the neighborhoods is extrapolated from U.S. Bureau of Economic Analysis estimates for the State of Rhode Island. A linear relationship between U.S.B.E.A. per capita income data and median household income data is assumed. A standard inflation multiplier of $119.8 \%$ is used to inflate 1979 income data for 1989. dollars (based on an assumption that income variations among the 25 neighborhoods have not changed between 1979 and 1989). The CACI 1989 Affordability Index is a Winsor Associates estimate based upon the CACI 1989 census tract median household income aggregated to the standard CDBG neighborhoods. The neighborhood numbers are derived from the Bureau of the Census neighborhood numbering system. These numbers will be used throughout the report to refer to the corresponding neighborhood where space will otherwise not permit. 
While rents more than doubled in all neighborhoods except Manton, the largest increases were in the poorer neighborhoods such as Hartford ( 376.2 percent), and Upper South Providence (271.9 percent). Moreover, in neighborhoods with the lowest incomes, the percentage of income paid for rents was the highest.

\subsection{Federal Legislation}

There are three pieces of federal legislation which focus on the needs of disabled. These are the Rehabilitation Act of 1973, as amended, the Architectural Barriers Act passed in 1968, and the Fair Housing Amendments Act of 1988. Each covers a specific facet in a growing body of civil rights law. The first addresses accessibility to programs; the second, physical barriers; and the third, landlord and tenant responsibilities.

\section{- Rehabilitation Act of 1973}

The most vital federal law affecting housing and people with disabilities is section 504 under Title $V$ of the Rehabilitation Act of 1973. This landmark civil rights legislation for people with disabilities states that no qualified handicapped person may be excluded for any program or activity supported by federal funds, or as a result of amendments in 1978, from any program or activity of the federal government itself.

Section 504 applies the broad definition of "handicapped" as meaning any person who has a physical or 
mental impairment which substantially limits one or more major life activities, who has a record of such an impairment, or who is regarded as having such an impairment.

The focus on "program or activity" moves the emphasis away from the built environment to the project. For example, if a federally funded substance abuse program is to be held on a school campus, only those buildings actually used in the program must be accessible so that no potential, qualified participant is turned away due to nonaccessibility. (It is important to note that these regulations cover all federally funded programs whether they be defense contracts or farm subsidies; not just HUD programs.)

"Program accessibility," which is the fundamental regulatory concept of section 504, means that the full range of program possibilities must be accessible. In terms of the Providence Housing Authority and the mandate for accessible housing, this can be translated to mean that the full range of developments and the full range of the variously sized housing units must be accessible. This does not mean that every unit be accessible, but rather that a portion of each development and a portion of each housing unit size must be accessible.

The United States Department of Housing and Urban Development (HUD) has stipulated what that portion is to be: 5 percent of the total number of housing units will be wheelchair accessible, and 2 percent of the total will be 
hearing or sight impaired accessible. HUD has also adopted the Uniform Federal Accessibility Standard (UFAS) as a guideline for new construction as well as rehabilitation.

- The Architectural Barriers Act

The second key federal statute is the Architectural Barriers Act (ABA) passed in 1968, requiring that federal and federally funded buildings and facilities be readily accessible to handicapped people. Standards were prepared by four different federal agencies: HUD, the Department of Defense, the General Services Administration, and the United states Postal Service. In 1984 the four agencies, in search of uniformity, issued a single set of standards under the $A B A$, the Uniform Federal Accessibility Standards (UFAS). The UFAS is based on the Minimum Guidelines and Requirements for Accessible Design developed by the United States Architectural Barriers Compliance Board, an agency established by section 502 of the Rehabilitation Act to ensure compliance with the standards issued under the ABA. UFAS is intended to bring consistency and uniformity to federal and federally funded design and construction.

These regulations are enforced for new construction, but with older buildings, accessibility standards are applicable only when rehabilitation or renovation is carried out.

- The Fair Housing Amendments Act

The most recent piece of federal legislation focuses not on buildings or programs, but rather works to build a 
framework within which landlord and tenant must operate in order to deal fairly with problems of access for the handicapped. The Fair Housing Amendments Act of 1988 prohibits housing discrimination based on color, religion, gender, national origin, or physical or mental handicap. The Act makes it unlawful:

- To discriminate in the sale or rental of housing to any buyer or renter because of handicap;

- To refuse to permit a tenant to modify the premises, at his or her own expense, if such changes are necessary to allow a person "full enjoyment" of the premises. The landlord may then expect, within reason, for the disabled tenant to return the premises to its previous state when the tenant moves;

- To refuse to make reasonable accommodations in rules, policies, practices or services when to do so would allow the tenant equal opportunity to enjoy the dwelling unit, common space and public areas;

- To fail to design multifamily units, for first occupancy after March 13, 1991, that are accessible or adaptable for handicapped people.

HUD's guidelines which will be published in the near future will also include the following requirements. In all dwellings falling under HUD regulation there must be at least one building entrance on a route from the street into the building, as well as all public and common-use areas 
being accessible to a wheelchair. In addition, all doors must accommodate a wheelchair; each unit must have an accessible route into and through it; electrical switches must be placed low on the walls; bathroom walls must be reinforced so they will support grab bars; and kitchens and bathrooms must be designed so that a wheelchair could maneuver within them. In elevator buildings all units must follow the above guidelines, in non-elevator buildings only those units on the first floor must be so accommodating. These requirements must be in place in all new construction to be ready for occupancy after March 13, 1991.

\section{- Remedies and Sanctions}

The remedies and sanctions for non-compliance with these federal statutes are considerable. HUD is able to withhold funding until corrective action takes place, and affected persons may file complaints with HUD which will initiate an investigation of compliance, as well as being able to collect damages and fees from the funded agency. It is therefore extremely important to the Providence Housing Authority, which currently is spending $\$ 25$ million on development and over $\$ 42$ million on modernization, to understand fully the obligations placed on the Authority and to carry out the mandate to provide for that portion of the disabled population falling within its scope of service.

Federal legislation displays a growing awareness within the Congress of the needs of disabled people, witnessed by the expanding body of guidelines and regulations produced by 
HUD. From the limited accessibility required in the Architectural Barriers Act to the explicit and broad demands engendered by the Fair Housing Amendment Act and the Rehabilitation Act amendments, those people with disabilities are beginning to see changes that will genuinely offer them accessibility to our society.

\subsection{Handicapped/Housing Legislation in Rhode Island}

The two pieces of Rhode Island legislation affecting disabled persons were originally passed in 1956. The Rhode Island Fair Housing Practices Law 34-37.4. asserts that "visually handicapped persons and other physically disabled persons shall be entitled to full and equal access, as other members of the general public, to all housing accommodations offered for rent, lease or compensation in this state..."

There is nothing in this legislation requiring any modification of real property to provide accessibility by either the government or by the property owners. Regarding enforcement of the law, a citizen may file a complaint with the Rhode Island Commission for Human Rights. If the Commission agrees with the complainant, the respondent is subject to a civil action by the complainant for damages sustained, payment of costs or punitive damages not to exceed $\$ 500$.

Discrimination against the Handicapped Law 42-87-1 reiterates the same statement on housing and the handicapped as the above. The major difference between the two laws is 
that under the latter, a complainant can bring an action in superior court directly, but only after the commission has failed to act within 60 days of receiving a complaint.

It is easily understood how the federal government, with the threat of withdrawal of funds, enjoinment or fines, can have a much greater effect on the production and maintenance of housing for disabled people than can state legislation with its limited enforcement. Even in legislation where the Rhode Island legislature has made funds available through Rhode Island Housing for the specific purpose of producing units for low income people, including the disabled, there are problems in producing the units, as noted previously.

With the tightening of budgets at all governmental levels, new ways must be found to produce housing for low and moderate income people, both able-bodied and disabled. The federal government, through the Reagan years systematically cut back on funding for affordable housing. Where originally the federal government was the lone support for the majority of housing efforts, the states and local municipalities have just begun to assume a broader role in response to the decrease in federal funding.

\subsection{Housing Initiatives}

- state Initiatives

Mary K. Nenno (1990), suggest several avenues available to state governments which will support housing production: 
- Housing Trust Funds - which are solely funded with state funds derived from a wide variety of sources such as real estate transfer taxes, state lottery receipts, appropriations from general funds, funds from previous state housing finance agency activity, etc.

- Public-Private Partnerships - which involve funding from businesses, banks and the state and which have specific housing goals for the development and preservation of affordable housing.

- State Fair Housing Requirements - which require a "fair share" distribution of low- and moderateincome housing responsibilities among the states municipalities, and state financial assistance in meeting the requirement.

- Assistance for Special Needs Households - which offers incentives for the development of housing for the frail elderly, the physically and mentally disabled and the homeless.

\section{- City Initiatives}

Possibilities for city government to take a more proactive role in the production of affordable housing include:

- Increased CDBG Housing Percentage - which would allow city government to direct housing dollars in the most productive manner and encourage the development of non-profit housing organizations. 
- A Housing Development Department - which would train and assist non-profits in producing, managing and maintaining affordable housing.

- City Housing Trust Fund - which would do locally what the state-wide housing trust fund does, only local1y.

- City Partnerships with Local Housing Authority which would allow the city to participate in new housing initiatives such as public housingsupported frail elderly care developments or group homes for deinstitutionalized people within public housing facilities.

\section{- Federal Initiatives}

While there still remains the hope that the federal government will once again restore the previous levels of funding, this seems unlikely in view of the federal deficit and budget requirements. What role then will the government be capable of playing that will support progress in the housing arena? Tax breaks and other methods of incentive financing could encourage affordable housing production; more comprehensive income supports or subsidies for poor people would allow broader housing choices; job training and child care programs would offer the low income people work alternatives and higher incomes; and expanded health programs would give more people a better start in life.

There is a critical need for thoughtful and well planned integration of housing, economic, community 
development and social services at all levels to best use limited funds. 
CHAPTER THREE

ANALYSIS OF FINDINGS

\subsection{Dept. of Housing and Urban Development Requirements} on June 2, 1988, HUD published the final rule in the Federal Register at FR 20216-20254, interpreting Section 504 of the Rehabilitation Act of 1973 for HUD funded agencies. Under section 504, qualified handicapped persons may not be excluded from any program or activity receiving federal financial assistance, such as loans and grants or, as a result of amendments in 1978, from any program or activity of the federal government.

The 5 percent and 2 percent requirements are applied to a "program in its entirety", meaning that percentages can vary somewhat from development to development. This is interpreted to mean that for existing housing, authorities must take "reasonable steps" to reach the 5 and 2 percent goals, but if problems such as inaccessible sites exist, or if the cost of adapting the units is excessive, HUD will allow a degree of flexibility. This is not the case with new development or the overall number of units within the housing authority. In these instances, HUD requires proof of undue financial hardship in order for a housing authority to produce fewer accessible units than required.

\footnotetext{
"Accessible" means that a dwelling unit or facility
} 
must be designed so that it can be approached, entered and used by people with handicaps. The requirements for accessibility are defined in the Uniform Federal Accessibility standards (UFAS) but may be superseded by more stringent state standards.

The schedule for completion of structural changes necessary to meet section 504 requirements is two years or by 11 July 1992. On a case-by-case basis the deadline may be extended by the Assistant Secretary for Fair Housing and Equal opportunity for an additional two years, to July 1994. The Secretary or Under Secretary may allow an additional one-year extension to July, 1995.

Throughout this report, numbers and figures used as PHA handicapped units include units currently in use and those funded although not yet constructed. This includes units at Chad Brown, Admiral Terrace, Manton Heights, Hartford Park, Scattered Site, Sunset Village and Dexter II (See FIGURE 2).

\subsection{PHA Inventory of Wheelchair and Hearing/sight Impaired} Accessible Units

- Provision of Handicapped Units Under section 504

There are 2,630 housing units in the Providence Housing Authority inventory. (PHA, 1989) During the Federal Fiscal Year 1991, the count has been temporarily reduced to 2,390 units due to the modernization of Hartford Park. As a 
result of the demolition of three high-rise buildings, the number of units in Hartford Park has decreased by 240 , from 748 to 508 . These 240 high-rise units are being replaced by 240 scattered site units of new development, the last of which is projected to be completed by June 1991. When these are completed, the number of PHA units will again be 2,630 .

Using 2,630 as the total number of PHA units, the federal requirement of 5 percent wheelchair accessible units and 2 percent hearing/sight impaired accessible units are listed below in TABLE 6 along with the number and percentages of the current and funded handicapped units.

TABLE 6

FEDERAL REQUIREMENTS AND CURRENT/FUNDED UNITS

\begin{tabular}{|c|c|c|c|c|}
\hline Unit Type & $\begin{array}{l}\text { HUD } \\
\text { Required }\end{array}$ & $\begin{array}{l}\text { HUD } \\
\text { Reoulyed }\end{array}$ & $\begin{array}{l}\text { Current/ } \\
\text { Funded : }\end{array}$ & $\begin{array}{l}\text { Current, } \\
\text { Sunded }\end{array}$ \\
\hline $\begin{array}{l}\text { Wheelchair } \\
\text { iccessible }\end{array}$ & 232 & 58 & 53 & 28 \\
\hline $\begin{array}{l}\text { :iear/sight } \\
\therefore \text { ccessible }\end{array}$ & 53 & 28 & 0 & 28 \\
\hline OOTALS & $\because 35$ & -8 & 53 & $=3$ \\
\hline
\end{tabular}

\section{- Current and Funded PHA Handicapped Units}

In TABLE 6, a total of fifty-three wheelchair accessible units and no hearing/sight impaired accessible units are currently available or funded. Of these totals, there are seventeen wheelchair accessible units in use at this time in the PHA: 11 one-bedroom, 4 two-bedroom and 2 three-bedroom. Sixteen wheelchair accessible units will be part of the complete modernization of Manton Heights, which 
should be on-line by mid-1993. These sixteen units consist of 3 one-bedroom, 8 two-bedroom and 5 three-bedroom units. At Hartford Park thirty-two new units will be constructed with eight units being wheelchair accessible: 4 two-bedroom units and 4 three-bedroom units.

In the scattered site program there are two apartments and 6 single-family houses that are handicapped accessible with four bedrooms each, and four single-family, handicapped accessible houses with five bedrooms which are slated to be completed by June 1991. This brings the total of wheelchair accessible units, current and funded, to fifty-three or 2 percent of the total PHA housing inventory.

TABLE 7 lists the current and funded units by elderly and family categories for each PHA development.

TABLE 7

CURRENT AND FUNDED WHEELCHAIR ACCESSIBLE UNITS

BY PHA DEVELOPMENT

\begin{tabular}{|c|c|c|c|c|c|c|c|}
\hline & $\begin{array}{l}\text { Family \& } \\
\text { Elderly Dev. }\end{array}$ & $0-B R$ & $1-B R$ & $2-B R$ & $3-B R$ & 4-BR & 5-BR \\
\hline \multirow{8}{*}{$\underset{\vec{E}}{\vec{E}}$} & Chad Brom & - & - & 2 & 1 & - & - \\
\hline & Admiral Ter. & - & - & 2 & 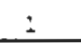 & - & - \\
\hline & Manton Hts. & - & 3 & 8 & 5 & - & - \\
\hline & Hartford Pk. & - & - & 4 & 4 & - & - \\
\hline & Codding $\mathrm{Ct}$. & - & - & - & - & - & - \\
\hline & Roger Whes. & - & - & - & - & - & - \\
\hline & $\begin{array}{l}\text { Scattered } \\
\text { Site }\end{array}$ & - & - & - & - & $\begin{array}{l}2 \text { apt } \\
6 \text { hou }\end{array}$ & 4 hou \\
\hline & sub-total & 3 & $?$ & 15 & 21 & 3 & 4 \\
\hline \multirow{9}{*}{$\begin{array}{l}\vec{a} \\
\frac{\vec{J}}{2}\end{array}$} & Sunset VIg. & - & 2 & - & - & - & - \\
\hline & Dexter I & - & - & - & - & - & - \\
\hline & Dexter II & - & 9 & 1 & - & - & - \\
\hline & Carroll Twr. & - & - & - & - & - & - \\
\hline & Kilmartin & - & - & - & - & - & - \\
\hline & Parenti & - & - & - & - & - & - \\
\hline & Dominica & - & - & - & - & - & - \\
\hline & Sub-total & 0 & 11 & 1 & 0 & 0 & 0 \\
\hline & TOTAL & 0 & 14 & 16 & 11 & 3 & 4 \\
\hline
\end{tabular}


out of the fifty-three total wheelchair accessible units, the one-bedroom units (11) are most prevalent in the elderly developments, and the two- and three-bedroom units (15 and 11, respectively) are most prevalent in the family developments.

In the elderly developments, only Dexter II, which was built in 1984, and sunset village which just completed modernization, have any wheelchair accessible units. (see FIGURE 1) The remainder of the elderly developments are in need of these units, but this will necessitate modernization funding and extensive reconfiguration of the buildings because the majority of the existing units are efficiencies.

of the fifty-three total PHA wheelchair accessible units, 22.6 percent are in the elderly developments. of the total PHA inventory, the elderly units comprise 38.8 percent. To maintain the same ratio of elderly units to family units for wheelchair accessible units as well as nonhandicapped units, nine additional elderly, wheelchair accessible units would need to be created.

This only addresses the current distribution of units and does not consider whether there is a higher percentage of handicapped people within the elderly population than there is within the family population. Nor does it answer the question of demand for this type of unit. 


\section{- Hearing and sight Impaired Accessible Units}

At this time there are no fully equipped hearing or sight impaired, accessible units in the PHA inventory. To meet the HUD 2 percent requirement, the PHA must be prepared to install, as needed, appropriate appliances or accessories to make units accessible for either hearing or sight impairments. Tenants and applicants must also be provided with information on the available accommodations.

Several deaf PHA residents have either put in blinking-light doorbells themselves or requested the Maintenance Department of the PHA to install the fixtures, but there has been no organized effort to fully accessorize the units of hearing or sight impaired residents.

As a result of the new HUD guidelines, as current PHA sight or hearing impaired residents are identified, their units will be retrofitted with the necessary adaptations by the PHA Maintenance Department. Each development must have these aids available to residents, in the number of units required by the HUD 2 percent guideline.

\subsection{PHA Disabled Population}

\section{- Current PHA Disabled Resident Population}

The population of the Providence Housing Authority as of February 1990 was 3,936 people; 2,836 in the family developments and 1,100 in the elderly developments. (PHA, 1989) The family residents comprise $72 \%$ of the PHA population and the elderly comprise $28 \%$. 
To determine what portion of the above PHA resident population was handicapped, supplemental security Income (SSI) figures for PHA residents were studied. SSI is a federal stipend paid monthly to people who have been evaluated and found to be either physically or mentally disabled.

Using SSI information supplied by residents on applications and recertification, social workers and housing management staff separated the handicapped residents into either the mentally handicapped or the physically handicapped category.

Using this procedure, of the 3,936 PHA residents, 8.1 percent or 319 people were identified as receiving SSI for physical disabilities and 3.8 percent or 150 people were receiving SSI benefits for mental disabilities.

TABLE 8 shows the distribution of mental and physical disability among PHA residents. 
TABLE 8

SSI RECIPIENTS BY PHA DEVELOPMENT

\begin{tabular}{|c|c|c|c|c|c|c|c|}
\hline \multicolumn{2}{|c|}{ Zeveiopment } & \multirow{2}{*}{$\begin{array}{l}\text { TOTAL } \\
\text { Number of } \\
\text { Residents } \\
546\end{array}$} & \multicolumn{2}{|c|}{$\begin{array}{l}\text { jSI } \\
\text { Reciplents } \\
\text { W/mental } \\
\text { disability } \\
\text { No. }\end{array}$} & \multicolumn{2}{|c|}{$\begin{array}{l}\text { ISI } \\
\text { Recipients } \\
\text { W/physical } \\
\text { disabli ity } \\
\text { io. }\end{array}$} & \multirow{2}{*}{$\begin{array}{l}\text { isI } \\
\text { Recipients } \\
\text { ds } \\
\text { Percent } \\
\text { of TOTAL } \\
2.88\end{array}$} \\
\hline \multirow{8}{*}{$\begin{array}{l}\stackrel{x}{\vec{b}} \\
\vec{\Xi} \\
\dot{E}\end{array}$} & Chad Brown & & 2 & .2 & 15 & 2.5 & \\
\hline & Admeral $\mathrm{T}$. & $\Xi 15$ & 3 & .6 & $i 7$ & 3.3 & 3.91 \\
\hline & Manton $\mathrm{H}$. & $: 37$ & 0 & 2 & $: 7$ & 2.3 & $2.3 t$ \\
\hline & Hacteord $P$ & $\$ 99$ & 9 & $\therefore .8$ & 34 & 6.8 & $8.6 *$ \\
\hline & Codding $c$. & $=54$ & $I$ & .4 & $: 2$ & 4.7 & 5.11 \\
\hline & Turnkey & $: 0$ & 4 & $\equiv .7$ & & 2.9 & a. 61 \\
\hline & Roger Wms. & 115 & 1 & .9 & $=$ & 2.7 & $2.6 t$ \\
\hline & scac. Site & 0 & 0 & כ & 0 & 0 & 0 \\
\hline & sub-tota 1 & 2.836 & 20 & .7 & 100 & 3.5 & 4.27 \\
\hline \multirow{7}{*}{$\begin{array}{l}2 \\
\vdots \\
\vdots \\
\vdots\end{array}$} & Sunset $V$. & 28 & 0 & 0 & 16 & 57.1 & 57.11 \\
\hline & Dexter I & $\therefore 15$ & 25 & $: 1.6$ & 22 & 10.2 & 21.84 \\
\hline & Cexter II & $: 21$ & $: 5$ & i3.5 & $: 7$ & \pm 5.3 & $=8.81$ \\
\hline & Carrol1 T. & $=15$ & 32 & $\$ 4.4$ & 35 & 16.3 & 20.71 \\
\hline & Kilmartin & 106 & 18 & 17.0 & 49 & 46.2 & 63.21 \\
\hline & Parenti & 208 & 17 & 8.2 & 60 & 28.9 & 37.1 t \\
\hline & Dominsca & 217 & 24 & 11.0 & 20 & 9.2 & 20.21 \\
\hline & Sub-total & $\therefore 100$ & 130 & 11.7 & 219 & 29.9 & 31.68 \\
\hline & TOTAL & 3.936 & 150 & 3.8 & 319 & 8.1 & 11.98 \\
\hline
\end{tabular}

The percentage (8.1) of physically disabled residents is not the percentage of physically disabled residents requiring wheelchair accessible units. The residents requiring wheelchair accessible units would be included in the 8.1 percent, but only as a sub-set of that group. The 319 SSI identified people would include the severely physically impaired people, but the scope of physical handicaps within the SSI grouping would be much broader, including people using canes and crutches, as well as wheelchair-bound people. Nevertheless, many of this larger group who are not severely disabled will at some time in the 
future come to depend on the extra help offered by the handicapped units. This includes the elderly and the chronically ill whose level of care will probably increase with age.

Although this study does not deal with mentally disabled residents of PHA developments, these people do impact the general resident population. As shown in TABLE 8, 11.7 percent of the entire elderly population is mentally disabled.

In Carroll Tower the percentage of mentally disabled people is almost 14.5 , bringing with it many problems of management and care. The perception that the mentally disabled bring chaos and fear into the elderly developments is very real to many of the elderly residents. The mentally disabled are not directly supervised by any state agency and a substantial number of the mentally disabled in the highrise buildings forget to take their medication or are substance abusers. The PHA does not currently have adequate funding or staff to extend the degree of care necessitated by these conditions to its residents.

The results of this lack of supervision are being addressed by the Planning and Special Services Department of the PHA with the help of The Providence center. The Providence Center has been designated by the state as the mental health center for the Providence Catchment Area, and many of the mentally disabled residents of the PHA are clients of The Providence center. 
The family developments have very low percentages of both types of disabilities. This is partially due to a lack of availability of handicapped units in the family developments, but it also results from the fact that many disabled people are afraid to live in the family developments. During interviews with service providers, several suggested that they had clients in need of subsidized, handicapped apartments, but that the clients refused to apply for residency in the family developments because they view them as dangerous. They would, on the other hand, be pleased to live in one of the scattered site units currently under construction.

The PHA is in an excellent position to change the negative perception of the family developments. Money is being spent through modernization to update the family units and make the development sites more attractive and safe. Now is the opportune time to reach out into the community, disabled and non- disabled, to encourage and reassure people that the PHA is making every effort to offers residents of Providence safe, decent and affordable housing.

\section{- Physically Disabled PHA Residents}

During research for this topic, senior staff members were asked to provide information regarding the type and extent of the disabilities of the residents listed as receiving SSI (a sub-set of the SSI physically disabled, TABLE 8). Those residents were recorded as having serious mobility, sight or hearing problems. 
This resulted in a total of sixty-three disabled tenants or 1.6 percent of the total PHA resident population: sixteen (25 percent) living in family developments and 47 (75 percent) living in elderly developments. The sixtythree total is 20 percent of the SSI recipients accounted for as physically handicapped. The major handicaps of these residents are:

$$
\begin{aligned}
& \text { Mobility . . } 41 \\
& \text { Blindness . . . } 13 \\
& \text { Deafness . . . } 7 \\
& \text { Mute } \quad \text { - } \quad \underline{2} \\
& \text { Total . . } 63
\end{aligned}
$$

These residents were invited by the PHA during the spring of 1990 to participate in focus groups aimed at learning about the problems of physically disabled people. Both the dwelling units as they are currently designed, and the common areas of the developments were discussed.

\section{- Physically Disabled Applicants}

The number of PHA disabled applicants as of 15 June 1990 was twenty-one or 1.5 percent of the total 1,400 applicant pool. This is very close to the percentage of disabled residents to total residents ( 1.6 percent). Ten of the applications were for family development units and eleven were for elderly units. The handicaps of the 
applicants are:

\begin{tabular}{|c|c|c|}
\hline Mobility & . . & . \\
\hline Blindness & . . & - \\
\hline Deafness & . . & - \\
\hline cotal & . & \\
\hline
\end{tabular}

Disabled applicants follow the same verification process as the non-disabled. These families may, however, qualify for a higher priority due to the "Federal Preference Guidelines" if they can document that their present housing "endangers the health, safety and well-being of the family." For example, a person in a wheelchair who lives on the second floor and must be carried upstairs would qualify for this priority. A letter from a doctor or social worker would be sufficient documentation.

There is also a "Handicap Verification" form (APPENDIX B) which a doctor can complete to verify a handicap for a person not receiving SSI. For example, this form would entitle a hearing impaired person who works (if he or she is a head of household or spouse) to a deduction from his or her rent because of the disability.

The Tenant selection office of the PHA does outreach to various social service agencies which aid the disabled. The PHA will be sending flyers or providing speakers for groups in order to encourage people to apply for public housing. 


\subsection{Units Needed to House Disabled Residents and Applicants}

At this time, no able-bodied people are living in any of the PHA handicapped units, but many disabled residents are living in non-handicapped units. To begin to determine the need for handicapped units within the PHA, TABLE 9 shows the discrepancy between the number of handicapped units needed to house both the current PHA handicapped population (as specified by the management) and applicants on the waiting list, and the number available. The demand for 0 5 bedroom units by both groups (residents and applicants) is compared with the number of current and funded PHA handicapped units. In this way the unfulfilled need for handicapped units, in the near future, can be indicated.

TABLE 9

DISCREPANCY IN HANDICAPPED UNITS NEEDED AND PROVIDED

\begin{tabular}{|c|c|c|c|c|c|c|}
\hline Units/Disabled & $0-3 R$ & $\therefore-5 R$ & $2-\mathrm{ER}$ & $2-\mathrm{BR}$ & $4-5 R$ & $5-B R$ \\
\hline Crnt., Fund d "nits & $?$ & i4 & .6 & $\therefore:$ & 3 & $\vdots$ \\
\hline Handc'p Tenants & $=4$ & 20 & $\therefore 2$ & $\div$ & 3 & $\therefore$ \\
\hline Handc'= Applicant & $\equiv$ & 2 & 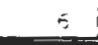 & $i$ & 3 & $\therefore$ \\
\hline Discrepancy & -29 & -8 & $-i$ & -3 & +2 & -2 \\
\hline
\end{tabular}

TABLE 9 indicates that the largest discrepancy in supply and demand exists in the smaller sized units. Adding together the efficiency $(0-B R)$ and one-bedroom numbers, the shortfall is currently thirty-seven units. These are taken together because efficiency apartments are not large enough to accommodate a disabled person, as mentioned previously in this report. This problem is almost exclusively a problem 
with the elderly in the high-rise buildings where most of the units are efficiencies and many of the households are for one person.

There is little demand for efficiencies or one-bedroom handicapped units in the family developments where space needs (usually for children) dictate larger units. Furthermore, development managers concur that, for safety reasons, single disabled people should generally be housed in the elderly developments.

The number of three-, four- and, five- bedroom units in TABLE 9 show a surplus, albeit a very small one. These figures do not address those handicapped families who, through income eligibility, outreach by the PHA and improvements in security and appearance, might look to the PHA for housing in the future.

\subsection{Social services Provided by the PHA}

The PHA Planning and Special Services Department was created in 1989 in response to the growing need to include social services as an essential element in the provision of safe and decent housing for PHA residents. Prior to that time, the only services available to the residents were from outside providers. Since 1989, the services provided by the PHA have increased as available funds have been found to support programs.

At this time the Director of Planning and Special Services of the PHA describes the provision of social 
services as "expanding." The Department hopes to continue increasing the current scope of services which includes social workers, drug prevention coordinators, youth programs, education programs, preparation for community living and senior transportation.

Some of these programs are provided in the PHA developments but are supported by outside agencies. See TABLE 10 for an inventory of social services provided for PHA residents.

TABLE 10 INVENTORY OF SOCIAL SERVICES AVAILABLE TO PHA RESIDENTS

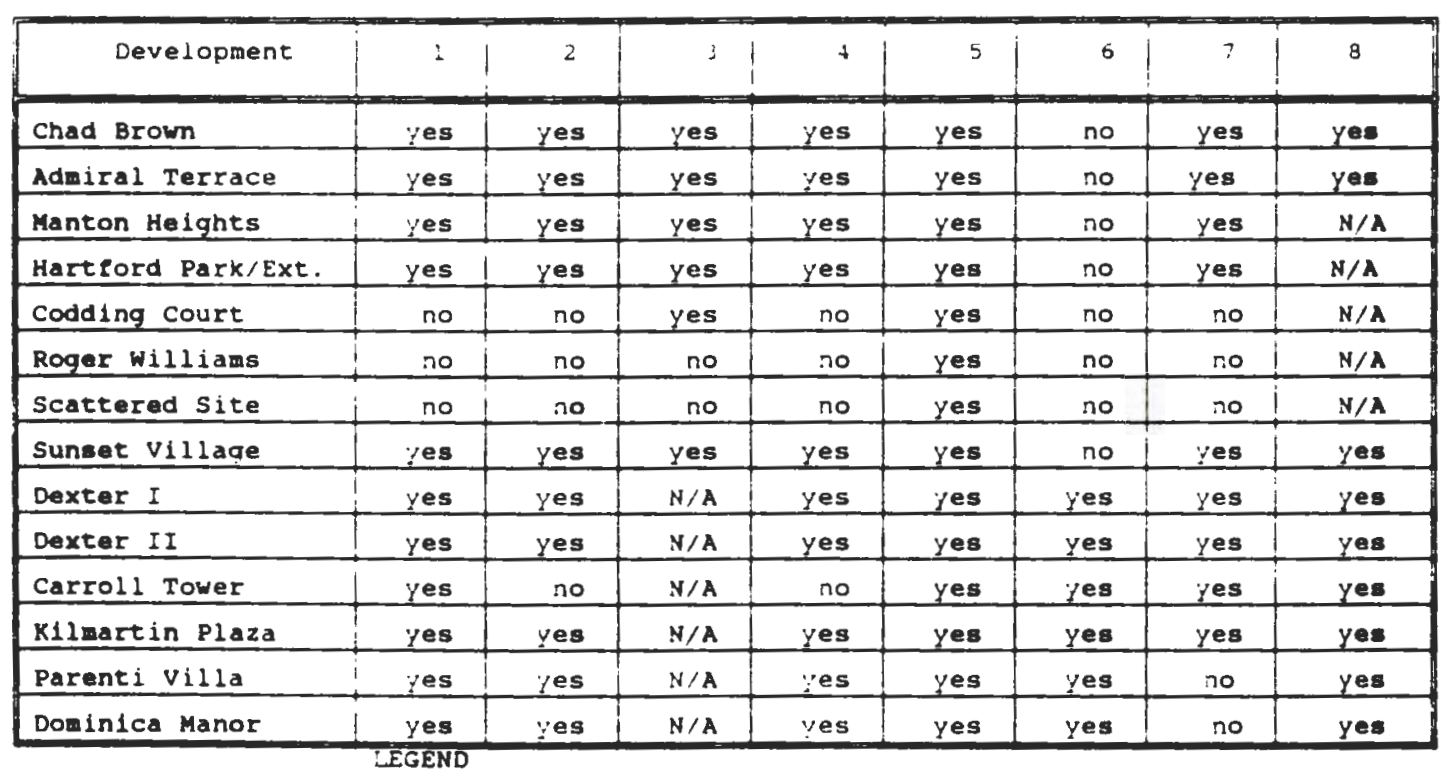

1. Social worker

2. Drug Prevention Prog.

3. Youth Program

5. Prep. for Community Living

4. Education Proaram

6. Visiting Nurse

i. Meal site

Source: PHA Planning and Special Services Department 


\section{- services for Disabled PHA Residents}

Although there are no programs specifically focused on the handicapped population of the PHA, disabled PHA residents do participate in the services available to all residents. Programs such as counseling, transportation for seniors, meals provided on site and visiting nurses are particularly relevant to disabled people. The Planning and Special Services Department is looking for funds to support disabled people and their specific needs.

\subsection{Citywide Inventory of Wheelchair Accessible Units - Methodology}

Using the "Listing of HUD Multifamily Housing" compiled by HUD, Providence office, the PHA conducted a telephone survey of all the HUD insured/subsidized Providence housing developments to identify the number of subsidized wheelchair accessible units available. Each development manager was asked how many wheelchair accessible units there were and the number of bedrooms in each. The name of each development and number and size of the handicapped units available are provided in APPENDIX $c$.

David spader, a volunteer from PARI Independent Living Services (a support agency for physically handicapped people), generated the appendix. Mr. Spader is planning to use this data as a first step in setting up a statewide housing referral service for disabled people. 


\section{- Results of the survey}

out of the seventy developments in Providence which were surveyed (PHA included), there were 7,633 subsidized housing units, 366 or 4.8 percent of which were wheelchair accessible. Thirty-six of the handicapped units were efficiencies ( 10 percent), 248 were one-bedroom units (68 percent), 58 were two-bedroom units (16 percent), 12 were three-bedrooms ( 3 percent), 8 were four-bedroom units (2 percent), and 4 were five-bedroom units ( 1 percent).

All of the three-bedroom units except one, as well as all the four- and five-bedroom units, are part of the PHA inventory. There appears to be a decided lack of larger units elsewhere in the city, leaving the support of larger families with disabled persons the responsibility of the PHA.

During the telephone survey it was discovered that although there were at least 366 wheelchair accessible units available throughout the city, many of them were rented by non-handicapped persons. Several of the managers stated that they had difficulty in finding handicapped tenants and many handicapped people did not know where suitable apartments were available.

The spatial distribution of wheelchair accessible units (PHA included) is shown by census tract (FIGURE 4) and by neighborhood (FIGURE 5). Census Tract 30 had the highest number of units (54) and Tracts $32,33,34,35$ and 36 were conspicuous by the absence of any subsidized units. (FIGURE 
FIGURE 4

HUD SUBSIDIZED WHEELCHAIR ACCESSIBLE UNITS IN PROVIDENCE

BY CENSUS TRACT

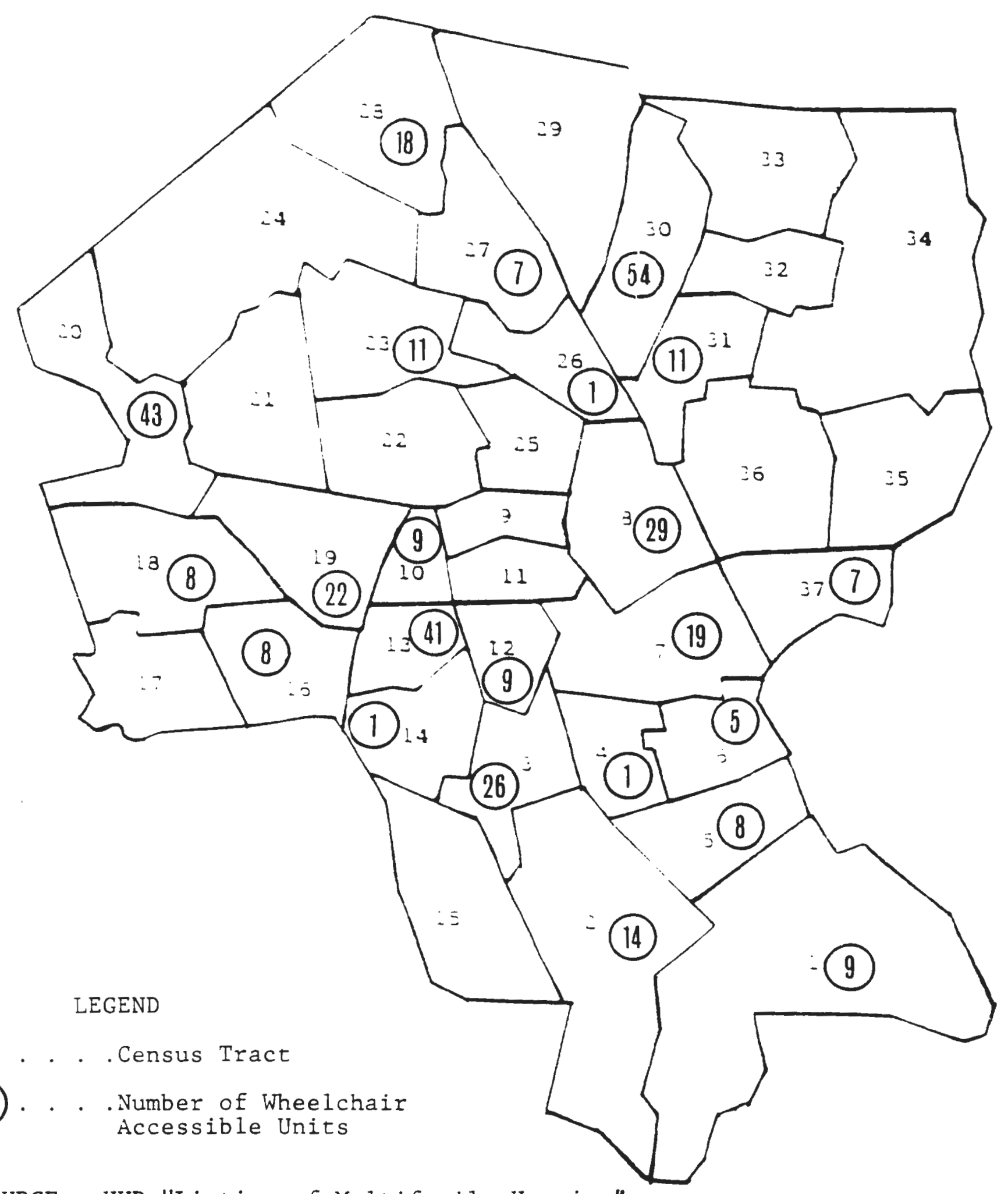

SOURCE: HUD "Iisting of Multifamily Housing" 
FIGURE 5

HUD SUBSIDIZED WHEELCHAIR ACCESSIBLE LNITS IN PROVIDENCE

BY NEIGHBORHOOD

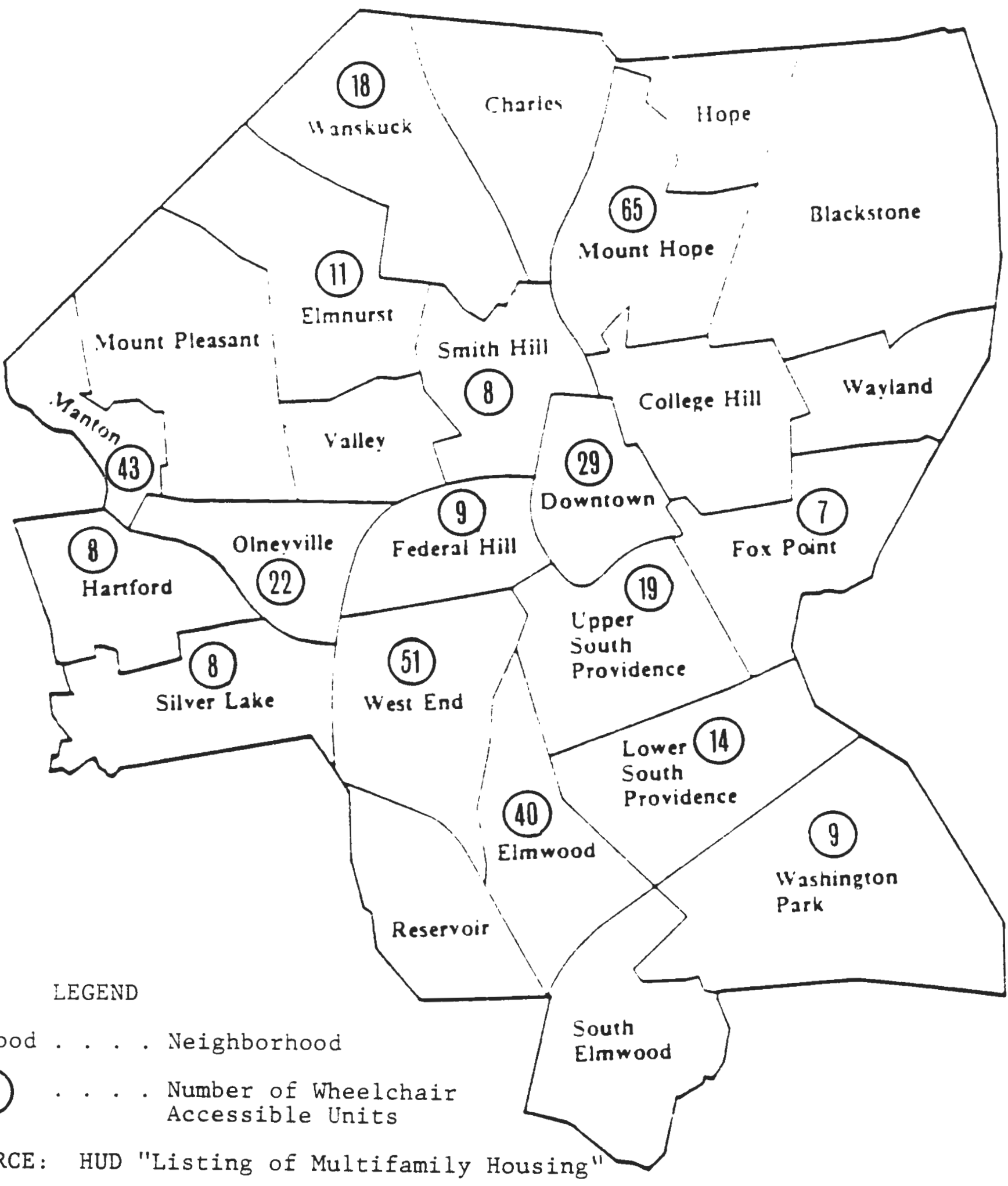

lmwood . . . Neighborhood

(40)... Number of Wheelchair

jOURCE: HUD "Listing of Multifamily Housing 
4) The majority of the units were in a path north to south, from Mount Hope (65) through Downtown (29) to the west End (51), Elmwood (40) and Upper South Providence (19) . (FIGURE

5) There were also sixty-five units in Manton and olneyville. This pattern coincides with the areas that house the less affluent population groups in the city.

- Future Development

The HUD Providence office reported that there is unlikely to be an increase of wheelchair accessible units in Providence in the near future, financed by HUD programs. Michael Dziok, Director of HUD's Development Division, stated that as of 29 June 1990 there were no approved projects, with wheelchair accessible units, in the pipeline.

\subsection{Citywide Estimate of Disabled Population}

\section{- Current Information}

Current figures relating to the number of physically handicapped people in Providence are not available. Neither the city nor the state tracks this population, and most agencies that service disabled people have limited information on their clients. The service agencies, because they focus on a small segment of the population, keep all their information on a statewide basis. Moreover, restricted funding makes statistics, the systems necessary to keep them current, and the staff to carry out research, close to impossible. Only Meeting street School, which serves developmentally disabled children, and the child 
Development center were able to produce the numbers of clients living in Providence and those receiving assistance.

- Methodology

The most current information on Rhode Island's disabled people was compiled in 1980 by the Governor's Committee on Employment of the Handicapped. These figures were used, along with the U S Census, 1980, and the D\&B - Donnelley Demographics population projection to determine an estimate of the disabled population in Providence, the subset of which was below 80 percent of median income, and the additional subset which was physically disabled. (See APPENDIX D)

The number of physically disabled people is not to be equated with the group of disabled people who require wheelchair accessible units. That group is a small subset of the larger physically disabled population. This study was not able to determine an acceptable number for this group due to lack of published information.

TABLE 11 shows the total Providence disabled population, the number of that group which is below 80 percent of median income and the number of that group which is physically disabled, as opposed to mentally or for disabled for health reasons. The types of physical disabilities and the percent of the total handicapped population of Providence are listed after the table. Again, there is no way of knowing what percent of each physically 
disability group, in each year, needs an accessible unit.

TABLE 11

PROVIDENCE HANDICAPPED POPUIATION FOR 1980, 1989, 1994

\begin{tabular}{|c|c|c|c|}
\hline zencrt & $\begin{array}{l}: 980 \\
:=201 \\
\end{array}$ & $\begin{aligned} 2739 \\
z-2: \operatorname{maced} \\
\end{aligned}$ & $\begin{array}{c}: 204 \\
z \text { zojected }\end{array}$ \\
\hline Prov. Cisabled Population & 24.133 & 4.718 & 24,834 \\
\hline \pm it ar below bo Median i & $: 5, \div 76$ & 5.740 & $: 5,-235$ \\
\hline $\begin{array}{l}\text { 7 of Physicaliy Disabled } \\
\text { at or Jelow } 80 \text { Median } 5\end{array}$ & 3.864 & $?, 006$ & 7,036 \\
\hline
\end{tabular}

The listing of physical disabilities and the percentage each represents of the total Providence disabled population (used in TABLE 11) is as follows:

$$
\begin{aligned}
& \text { Hearing Impairment . . . . . . 4.5\% } \\
& \text { Vision Impairment . . . . . . } 8.9 \% \\
& \text { Amputee . . . . . . . . . 2.8\% } \\
& \text { Non-paralytic Orthopedic . . . . } 13.1 \% \\
& \text { stroke... . . . . . . . . } 3.98 \\
& \text { Spinal Cord Injury . . . . . . . } 1.98 \\
& \text { Arthritis . . . . . . . . } 13.6 \% \\
& \text { Multiple sclerosis . . . . . . } 0.3 \% \\
& \text { Polio.............. . . . } 0.98 \\
& \text { Muscular Dystrophy . . . . . . 1.4\% } \\
& \text { Cerebral Palsy . . . . . . . . . 2.5\% }
\end{aligned}
$$


points out that there is a group of people within the general population about which little is known, while the needs of this group are substantial. The PHA is working to offer those people who have limited incomes, safe and decent housing.

\subsection{Resident and Community Input}

This section addresses additional findings from the qualitative research of the focus groups, interviews with service providers, and recommendations arising from the physical analysis of the PHA housing stock in conjunction with the HUD requirements.

Many of the problems of accessibility within the PHA housing developments are best understood by the disabled residents themselves. In order to get the broadest possible response, the PHA Housing Management Department, in May and June of 1990, notified directly the sixty-three, seriously disabled residents that their input was requested. Twentyeight disabled tenants attended one of the meetings.

Meetings were held in nine of the developments during the early summer to discuss what improvements the physically disabled residents would like to see initiated by the PHA. Four basic areas were covered: accessibility within the dwelling units, accessibility in the non-dwelling unit areas, social service provision and quality of life. Three staff members were present during the discussions, one from the Modernization and Development Department, one from the 
Housing Management Department and one from the Maintenance Department.

During this period interviews were also held with area service providers such as the MS Society, R I Project Aids, Insight and PARI Independent Living service; government agencies such as R I Department of Vocational Rehabilitation, Providence Department of Human Services and R I Department of Elderly Affairs; and Mayor's Commission on the Handicapped and the Governor's Commission on the Handicapped. The representatives of all these groups were asked what they knew of the physically disabled population in Providence and what suggestions they might make from their area of expertise regarding housing for the low and moderate income physically disabled people.

\section{- suggestions on Unit size}

At the meetings with PHA physically disabled residents, apartment size was one of the major issues. There was a general agreement that one-bedroom units were most appropriate for the elderly developments and the two- and three-bedroom units were most needed in the family developments.

The disabled residents from the highrise buildings, many of whom live in efficiency apartments, felt that efficiency units were too small to accommodate a disabled person. The consensus was that a one-bedroom unit was the most comfortable for one person, and a two-bedroom unit was best suited for two people, if one was handicapped. The 
residents also stated that disabled people should live on the lower floors to make exiting the building easier in case of an emergency, and that blind people should have units close to the elevators.

At the meetings for the disabled in the family development meetings, the residents also felt that space was the most important commodity. As in the elderly buildings, it was stated that a family of two with one person handicapped needed the extra space afforded by two-bedrooms. A disabled person requires a room for himself or herself because of physical discomfort and/or for the machinery or equipment needed for health maintenance. If there are children in the family, then the need for bedrooms increases to three, four or five.

Diane Martin, Clinic Coordinator of the Child Development Center at Rhode Island Hospital recorded 112 cases of orthopedically handicapped children, living in Providence, who are also on medical assistance. She stated, "The majority of these families live in tenement houses which make it very difficult for these children to go in and out of their homes. Many are carried in their wheelchairs up and down stairs which is a very unsafe situation to say the least. The vast majority of these children have siblings which would necessitate a three-bedroom home."

\section{- suggestions for social services}

Some of the ideas suggested by PHA residents for improving social services for the disabled living in PHA 
developments are:

- A system be arranged for residents to receive temporary medical assistance. For example, a resident is in need of eye drops four times a day until she has her cataract removed. Someone helps her twice a day, but she has to do it herself twice. She is very nervous and spills the drops. If she had someone to assist her over the next few weeks, it would help.

- A buddy system be established which would pair ablebodied residents with handicapped residents for the purpose of assisting in case of an emergency.

- People are very often inconsiderate of handicapped persons, particularly in the family developments. A session explaining about disabled people and how to treat them should be included as part of the Living Skills program (a series of classes attended by every new PHA tenant at which housekeeping and community responsibility are taught).

- There is a serious lack of transportation for handicapped residents and additional vans are needed.

- Programs aimed at supporting the integration of young disabled people into the general community are needed.

- More advocacy for handicapped people is needed both within the PHA and in the wider community. For example, many of the city bus shelters are placed in the middle of the sidewalks, making wheelchair passage impossible. A staff member or group of disabled PHA 
residents to listen and speak up for handicapped needs would help.

\section{- 8uggestions for the Visually Impaired}

The representation of blind and deaf people at the meetings of PHA handicapped residents was small and not very vocal. These handicaps seem to have a much greater social impact on people, leaving them more isolated than mobility handicapped people. Special attention should be given to assisting blind and deaf people in dealing with both social and physical limitations.

Caldy schire, a rehabilitation instructor from Insight, a multi-service agency for the vision impaired, suggested ways in which to aid blind people in coping with their environment:

- Large dials on stoves, thermostats, etc.

- Non-glare, bright lights throughout unit

- Shallow storage spaces

- Notices written in large print or on tape

- Signature lines in heavy magic marker

- Apartments near the elevators

- Extra security at the entrance doors as blind people feel very vulnerable when groping with locks and keys

- Mailboxes at the edges of the bank of mailboxes and marked with tactile tape 


\section{- suggestions Most Often Requested}

There were certain requests that were repeated at almost all the resident meetings. These items are listed below: of the meetings:

- Grab bars by every toilet and tub

- Roll-in showers

- Handrails in hallways (both sides if possible)

- Slower-closing elevator doors

- Front doors that are easier to open

- More well-placed curb cuts

- More handicap parking with stricter enforcement

- More and lower emergency cords within the units

- Larger and lower peep holes

- Accessible public rest rooms

- Buddy-system for emergencies

- More aids for blind and deaf persons

The residents were also in general agreement that disabled people should not live in efficiency units as there was not enough space for equipment; that handicapped people should live on the first two floors of highrise buildings; and that blind people should have units near elevators.

One item deserves special attention not only because it was brought up at all the PHA meetings, but because it was also mentioned by every service provider for the mobility impaired. Everyone agreed that a wheel-in shower offered wheelchair users the greatest amount of self-sufficiency. 
However, wheel-in showers are very expensive to install and not so convenient for able-bodied adults and children. This is a design and financial problem that the PHA must address.

\subsection{Physical Accessibility}

- Accesaibility to Non-Dwelling Areas

HUD requirements for section 504 federal regulations for handicapped accessibility include both access within the dwelling unit and access to the unit. Handicap access to the unit involves providing an "accessible route" (a wheelchair must be able to move from public transportation, development roads or driveways and sidewalks up to the entrance), an accessible entrance to the building, and accessible common areas, public rest rooms and elevators.

The Providence Housing Authority Maintenance Department conducted a survey of all the developments to ascertain whether the approach, entrance, common areas, public rest rooms and elevators were accessible. TABLE 12 shows the findings by development. 
TABLE 12

WHEELCHAIR ACCESSIBILITY TO NON-DWELLING UNIT AREAS

BY DEVELOPMENT

\begin{tabular}{|c|c|c|c|c|c|}
\hline Development & $\begin{array}{l}\text { Acces- } \\
\text { sible } \\
\text { route }\end{array}$ & Entrance & $\begin{array}{l}\text { Cormon } \\
\text { ireas }\end{array}$ & $\begin{array}{l}\text { Public } \\
\text { Rest } \\
\text { Rooms }\end{array}$ & $\begin{array}{c}\text { Eleva- } \\
\text { = } 0 \text { Is }\end{array}$ \\
\hline Chad Brown & yes & yes & fes & yes & $\because, \mathrm{A}$ \\
\hline Admiral Terr. & yes & yes & yes & yes & $y \cdot A$ \\
\hline Manton Hes. & yes & yes & yes & yes & $N / A$ \\
\hline Hartford Pk. & yes & yes & $: I / \mathbf{A}$ & $y / A$ & $\because / A$ \\
\hline Ccdding $c t$. & no & .0 & 70 & no & $\because A$ \\
\hline Roger Wms. & no & no & $N / A$ & $N / A$ & $\therefore / A$ \\
\hline Scat'd Site & yes & yes & $N / A$ & $N / A$ & $\because A$ \\
\hline Sunset vig. & yes & yes & no & no & $\mathrm{N} / \mathrm{A}$ \\
\hline Dexter I & yes & yes & yes & no & yes \\
\hline Dexter II & yes & yes & yes & no & yes \\
\hline Carroll rar. & yes & yes & zes & no & $\therefore$ es \\
\hline kilmartin & yes & $\because$ es & Yes & ro & es \\
\hline Parenti & yes & yes & yes & no & $\because$ es \\
\hline Doninica & yes & yes & yes & no & yes \\
\hline
\end{tabular}

Most of the buildings in the PHA inventory were originally constructed prior to the general understanding of the importance of extended accessibility for disabled people. Therefore, many of the elderly buildings have accessible entrances, but do not have wheelchair accessible public rest rooms or wheelchair accessible elements within the apartments.

In the family developments, Chad Brown and Admiral Terrace, which have recently completed modernization, all non-dwelling elements are accessible. Manton Heights and Hartford Park are undergoing modernization and will be accessible when completed. The percentage of scattered site units that are designated as handicapped accessible 
will be so upon completion of construction. Neither Codding Court or Roger Williams Homes are accessible.

\subsection{0 summary}

- PHA Demand for Handicapped Housing

In response to section 504 of the Rehabilitation Act of 1973, HUD has placed quotas for handicapped units on all public housing authorities. The Providence Housing Authority must provide 132 wheelchair accessible units and 53 hearing or sight impaired units. The PHA has fifty-three wheelchair accessible units either currently or funded through modernization now underway. Seventy-nine more are needed to meet the quota.

The PHA has no fully equipped hearing or sight impaired units. The federal requirements are fifty-three of these units, but it also stipulates that they can be retrofitted on an as-needed basis up to the number or percentage required.

Using SSI information first 319 residents were identified as physically disabled. Then a sub-set of that group which was seriously disabled was isolated, bringing the total of residents needing handicapped equipped apartments to sixty-three. The applicant pool for the PHA was studied and twenty-one seriously disabled public housing applicants were identified.

Comparing the number of wheelchair accessible units needed by both residents and applicants (56), and the number 
of wheelchair accessible units current and funded (53), the result is a surplus of three. HUD is requiring 132 wheelchair accessible units, leaving a surplus of 135 . Under present conditions, the PHA will be able to absorb the current and near future physically disabled resident population.

\section{- Impact of Citywide supply and Demand}

In spite of the lack of crisis shown in the PHA estimate of need for wheelchair accessible handicapped units, there still remains a largely undetermined physically disabled population within the city of Providence which includes a smaller sub-set of people requiring wheelchair accessible units. With many of the 366 wheelchair accessible units occupied by able-bodied people, and most disabled people living in non-accessible units, there is no definitive supply and demand relationship.

It has not been documented as to why more disabled people requiring wheelchair accessible units have not placed a greater demand on the PHA for housing, but two reasons were suggested by PHA residents and staff, and community service providers:

- There is a lack of outreach into the handicapped community by all housing providers. At the same time there has been a lack of organized effort by the handicapped community to centralize housing information. This is partially due to the fact that handicapped apartments have not been well 
marketed or in great supply, so that handicapped people have not had reason to establish a strong housing network. The HUD requirements may well be a stimulus to both the production and appropriate occupancy of these units. There is a stigma attached to public housing for handicapped people who, for good reason, have a great concern for physical safety. Handicapped people will normally avoid an environment that has a reputation of drug problems and crime. This feeling extends beyond the handicapped population into the general community. The PHA is making every effort through its planning and Social Services, Housing Management and Maintenance Departments to address these problems.

The expansion of housing opportunity to the disabled people in our community is essential, as it is part of the mission of the PHA to serve the low income residents of Providence. Because this population is relatively untapped, and undefined, the number of wheelchair accessible units should exceed the expressed need of current PHA tenants and applicants. This assumption is supported by the lack of handicapped housing to be constructed with HUD funding in the near future. An effort should be made to approach as closely as possible, the number of handicapped units required by HUD. 
We need to learn more about the needs of the general population of disabled people and their housing of choice. Are they willing to move from their neighborhoods into public housing, particularly if the disabled person is not the head of household? Other governmental agencies such as Rhode Island Housing with its special Needs program to modify homes for persons with disabilities should serve people who choose not to relocate.

The PHA needs to continue its investigation of the disabled population including market studies focused on the demand for additional subsidized housing. The scope on housing needs of the disabled population cannot be met by one agency. The PHA should not and cannot assume the obligation to house all these people, but it can lead the way by offering well-designed affordable housing to the physically disabled. 
CHAPTER FOUR

RECOMMENDATIONS

\subsection{Introduction}

This chapter provides specific plans for conversion of units within each of the developments to wheelchair accessible units, as well as the construction of new handicapped units. Each development has been analyzed and the obstacles to accessibility studied. After weighing the obstacles, financial and/or structural, against the HUD requirements, a plan is presented.

\subsection{The Plan}

\section{- Hearing and sight Impaired Accessible Units}

The hearing and sight impaired accessibility element of the Plan as it applies to existing housing will be implemented through the retrofitting of units as disabled residents are identified. Where new units are under construction, 2 percent will be fitted with all necessary equipment.

\section{- Wheelchair Accessible Units}

1. Chad Brown 198 Units

$5 \%$ Wheelchair Requirement $=10$ Units ( 3 Currently)

$2 \%$ Hear $/$ Sight Requirement $=4$ Units ( 0 Currently)

A. Conditions: Chad Brown has recently completed modernization. There are only three, first floor units in the development and all of them are one-bedroom. 
Because conversion to handicapped always results in losing one bedroom, these units would be unacceptable as efficiencies. All other units are row houses with bath and bedrooms on the second floor making design changes prohibitively costly.

B. Recommended Action: None of the existing units lend themselves to conversion to handicapped accessible due to size and configuration. No additional handicapped units are planned.

2. Admiral Terrace 162 Units

$5 \%$ Wheelchair Requirement $=8$ Units ( 2 currently)

$2 \%$ Hear/Sight Requirement $=3$ Units ( 0 currently)

A. Conditions: Admiral Terrace has recently completed modernization in conjunction with chad Brown. All nonhandicapped units are row houses with bath and bedrooms on the second floor making conversion costly.

B. Recommended Action: None of the existing units lend themselves to conversion to handicapped accessible units due to configuration. No additional handicapped units are planned.

3. Manton Heights 330 Units

5\% Wheelchair Requirement $=16$ Units (16 Funded)

$2 \%$ Hear $/$ Sight Requirement $=7$ Units $(0$ currently) 


\section{A. Conditions: None}

B. Recommended Action: Partial funding has been received from the Comprehensive Improvement Assistance Program (CIAP) for the complete modernization of Manton Heights, including the conversion of 16 units to wheelchair accessibility. A construction contract for Phase I is expected to be awarded in August/September, 1990 with completion in approximately 2 years. Common spaces and accessible routes will also be addressed through modernization.

4. Hartford Park/Extension 508 Units 58 Wheelchair Requirement $=25$ Units ( 8 Funded) 28 Hear/Sight Requirement $=10$ Units ( 0 currently) A. Conditions: Partial funding has been received from CIAP and Major Reconstruction of Obsolete Properties (MROP) for the modernization of Hartford Park. Because of both structural and financial reasons none of the existing units can be converted to handicapped units. B. Recommended Action: Thirty-two new units have been funded and will be constructed on the site. Of these 32 units, 8 will be wheelchair accessible. Common spaces and accessible routes will also be addressed during modernization.

5. Codding court 119 Units $5 \%$ Wheelchair Requirement $=6$ Units ( 0 Currently) 
2 f Hear/Sight Requirement $=2$ Units (0 Currently)

A. Conditions: Common area and public rest rooms are not handicapped accessible. In the five buildings within the development there are 11 one-bedroom units, 18 two-bedroom units, 8 three-bedroom units, and 2 four-bedroom units on the first floors.

B. Recommended Action: Funds for planning have been requested in both the 1989 and 1990 CIAP applications. The PHA will continue to request funds for initial planning for modernization. In the interim, the PHA will request funding for the handicapped units separately in its 1991 CIAP application. Six handicapped accessible units will result from modernization; 4 units will have 2 bedrooms and 2 units will have 3 bedrooms. Common spaces and accessible routes will also be addressed during modernization. However, the community room, which is in the basement of one of the buildings, does not lend itself to conversion due to structural and financial reasons.

6. Roger Williams 40 Units

5\% Wheelchair Requirement $=2$ Units ( 0 Currently) $2 \%$ Hear/Sight Requirement $=1$ Unit (0 Currently) A. Conditions: Roger williams is not scheduled for modernization in the near future. The development consists of 2 buildings which have a total of 4 onebedroom units, 4 two-bedroom units, 4 three-bedroom 
units and 4 four-bedroom units on the first floors. B. Recommended Action: Funds to retrofit 2 units for wheelchair accessibility will be requested in the 1991 CIAP application. It is anticipated that 1 two-bedroom unit and 1 three-bedroom unit will be created. Common spaces and accessible routes will also be addressed during modernization.

7. Scattered Site 252 Units $5 \%$ Wheelchair Requirement $=13$ Units (13 funded) 28 Hear/Sight Requirement $=5$ Units ( 0 funded) A. Obstacles: None

B. Recommended Action: Twelve units have been completed and funds have been reserved for construction of 240 more units. Seven handicapped units have been contracted for with six additional units to be included in the second phase of construction. All units are expected to be completed by the summer of 1991 .

8. Sunset Village 24 Units 5\% Wheelchair Requirement $=1$ Unit (2 Currently) $2 \%$ Hear/Sight Requirement $=1$ Unit (0 Currently) A. Conditions: Sunset Village has recently completed modernization in conjunction with Chad Brown and Admiral Terrace. It has the required number of wheelchair accessible units, but the common room is on the second floor and the public rest rooms are not 
accessible.

B. Recommended Action: FY 1991 CIAP funds will be requested to address all outstanding handicapped accessibility issues. At this time it does not seem feasible from either a structural or financial point of view to make the second floor common areas handicapped accessible. The residents of sunset village can and do make use of the Chad Brown/Admiral Terrace community facilities, including a community center, nearby which are accessible.

9. Dexter I 200 Units

58 Wheelchair Requirement $=10$ Units ( 0 Currently)

$2 \%$ Hear $/$ Sight Requirement $=4$ Units (0 Currently)

A. Conditions: The elevator doors close too quickly, the sidewalks are uneven making wheelchair travel difficult, and the public rest rooms are not wheelchair accessible and none of the units are handicapped accessible.

B. Recommended Action: Elevator adjustments will be made in-house. Funds for making the public rest rooms wheelchair accessible and the sidewalks more even will be requested in the FY 1991, along with a request for modernization funding. In order to provide sufficient wheelchair accessible units, apartments will have to be reconfigured, probably resulting in the loss of 1 unit 
for every 2 one-bedroom handicapped accessible units created. A total of 6 additional handicapped units will be created. When combined with the number of Dexter II handicapped units (10), the total will be one handicapped unit above the $5 \%$ requirement (15). FY 1991 CIAP funds will be requested to address all outstanding handicapped accessibility issues, as well as using operating dollars for low cost items.

10. Dexter II 91 Units $5 \%$ Wheelchair Requirement $=5$ Units (10 Currently) 28 Hear/Sight Requirement $=2$ Units ( 0 currently) A. Obstacles: Dexter shares common space with Dexter I, therefore, the public rest rooms are not accessible, the sidewalks are uneven and the elevators close too quickly.

B. Recommended Action: See Dexter I

11. Carroll Tower 198 Units $5 \%$ Wheelchair Requirement $=10$ Units ( 0 Currently) $2 \%$ Hear/Sight Requirement $=4$ Units ( 0 Currently) A. Conditions: Front doors are very heavy for residents in wheelchairs to manipulate easily. B. Recommended Action: Funds for planning the retrofitting of units for wheelchair accessibility, as 
well as all outstanding handicapped accessibility issues will be requested in the FY 1991 CIAP application.

12. Kilmartin Plaza 106 Units

$5 \%$ Wheelchair Requirement $=5$ Units ( 0 currently)

2 Hear/Sight Requirement $=2$ Units ( 0 currently)

A. Conditions: Public rest rooms are not wheelchair accessible.

B. Recommended Action: Funds for planning the retrofitting of units for wheelchair accessibility, as well as all outstanding handicapped accessibility issues, will be requested in the FY 1991 CIAP application.

13. Parenti Villa 198 Units 5\% Wheelchair Requirement $=10$ Units ( 0 currently) 2 Hear/Sight Requirement $=4$ units ( 0 currently) A. Conditions: Front doors are very heavy for wheelchair people to manipulate easily, and public rest rooms are not wheelchair accessible.

B. Recommended Action: Funds for planning the retrofitting of units for wheelchair accessibility, as well as all outstanding handicapped accessibility issues, will be requested in the FY 1991 CIAP application. 
14. Dominica Manor 204 Units

5\% Wheelchair Requirement $=10$ Units ( 0 Currently)

2\% Hear/Sight Requirement $=4$ Units (0 Currently)

A. Conditions: Front doors are very heavy for wheelchair people to manipulate, and a curb cut is needed directly in front of the main entrance door.

B. Recommended Action: Funds for planning the retrofitting of units for wheelchair accessibility, as well as all outstanding handicapped accessibility issues, will be requested in the FY 1991 CIAP application.

\subsection{Conclusion}

The physical improvements listed above are merely the first step toward meeting the needs of physically disabled people by addressing the minimum HUD requirements of Section 504, Title V of the Rehabilitation Act of 1973. The next step for the Providence Housing Authority is to acquire funding that will produce these changes. HUD, through the Comprehensive Improvement Assistance Program, must provide funds with which housing authorities can implement the regulations. Furthermore, other avenues for funding must be explored.

Dealing equitably with the physically disabled population is an ongoing process, one that has just begun. Learning more about the numbers and conditions of these people is imperative. Information is at a minimum, a 
condition that must change before the problems of housing for the physically disabled can be creatively met. Responsibility for gathering this information must partially fall on the disabled themselves. It would expedite assistance to the disabled if an organization such as PARI (see CHAPTER 3, Citywide Inventory of wheelchair Accessible Units) which already is a center for information for disabled people in Rhode Island, could acquire additional funding and focus on defining the disabled population and its needs.

The Providence Housing Authority has just begun to address issues around the disabled, and the production of units to serve this constituency is just beginning. Cooperation between local, state and federal governments is essential in acquiring funding for accessible units as well as for the integration of disabled people into our society. 


\section{Bibliography}

Eisenberg, M., C. Griggins and R. Duval, 1982, Springer Series on Rehabilitation, Vol. 2, "Disabled Persons as Second-Class Citizens", Springer Publishing Company: New York.

Goldman, C., Esq., 1987, Disability Rights Guide, Media Publishing: Lincoln, NA.

The Governor's Comittee on Employment of the Handicapped, 1980, "The 1980 Rhode Island Census on Disabled Persons": Providence, RI.

Hedge, S., 1990, Housing Needs Assessment of Persons with Disabilities in Phode Island, prepared for Rhode Island Housing and Mortgage Finance corporation: Providence, RI.

Hughes, J. and G. Sternlieb, 1987, The Dynamics of America's Housing, Rutgers University, Center for Urban Policy Research: New Brunswick, NJ.

Mcclellan, G. (Ed.), 1974, Crisis in Urban Housing, The H. W. Wilson Company: New York.

Mental Health Law Praject, 1989, "Rights of Tenants with Disabilities Under the Fair Housing Amendments Act of 1988": Washington, D.C.

Mitchell, J. (Ed.), 1985, Federal Housing Policy and Programs, Past and Present, Rutgers University, Center for Urban Policy Research: New Brunswick, NJ.

Montgomery, R. and D. Marshall (Eds.), 1988, Housing Policy for the $1980^{\prime}$ 's, D. C. Heath and Company, Lexington Books: Lexington, MA.

Nenno, M., 1989, Housing and Community Development: Maturing Functions of State and Local Governments, National Association of Housing and Redevelopment Officials, Publication No. N901: Washington, D.C.

Nenno, M and G. Colyer, 1988, New Money and New Methods, A Catalog of state and Local Initiatives in Housing and Community Developent, National Association of Housing and Redevelopment officials, Publication No. 700: Washington, D.C.

Pimental, A., Ph.D., 1983, "Integration Not Assimilation", Disabled USA, The President's Comittee on Employment of the Handicapped: Washington, D.C. 
Schwartz, D., R. Ferlauto and D. Hoffman, 1988, A New Housing Policy For America, Recapturing the American Dream, Temple University Press, National Center for Policy Alternatives: Philadelphia.

U.S. House of Representatives, "Section 202 Housing Budget Crisis, A Report by the Chairman of the select Committee on Aging", U.S. Government Printing office, Committee Publication No. 100-682: Washington, D.C.

Winsor Associates and Albert Veri and Associates, 1990, Housing study for the city of Providence: Providence, RI. 
Appendices 


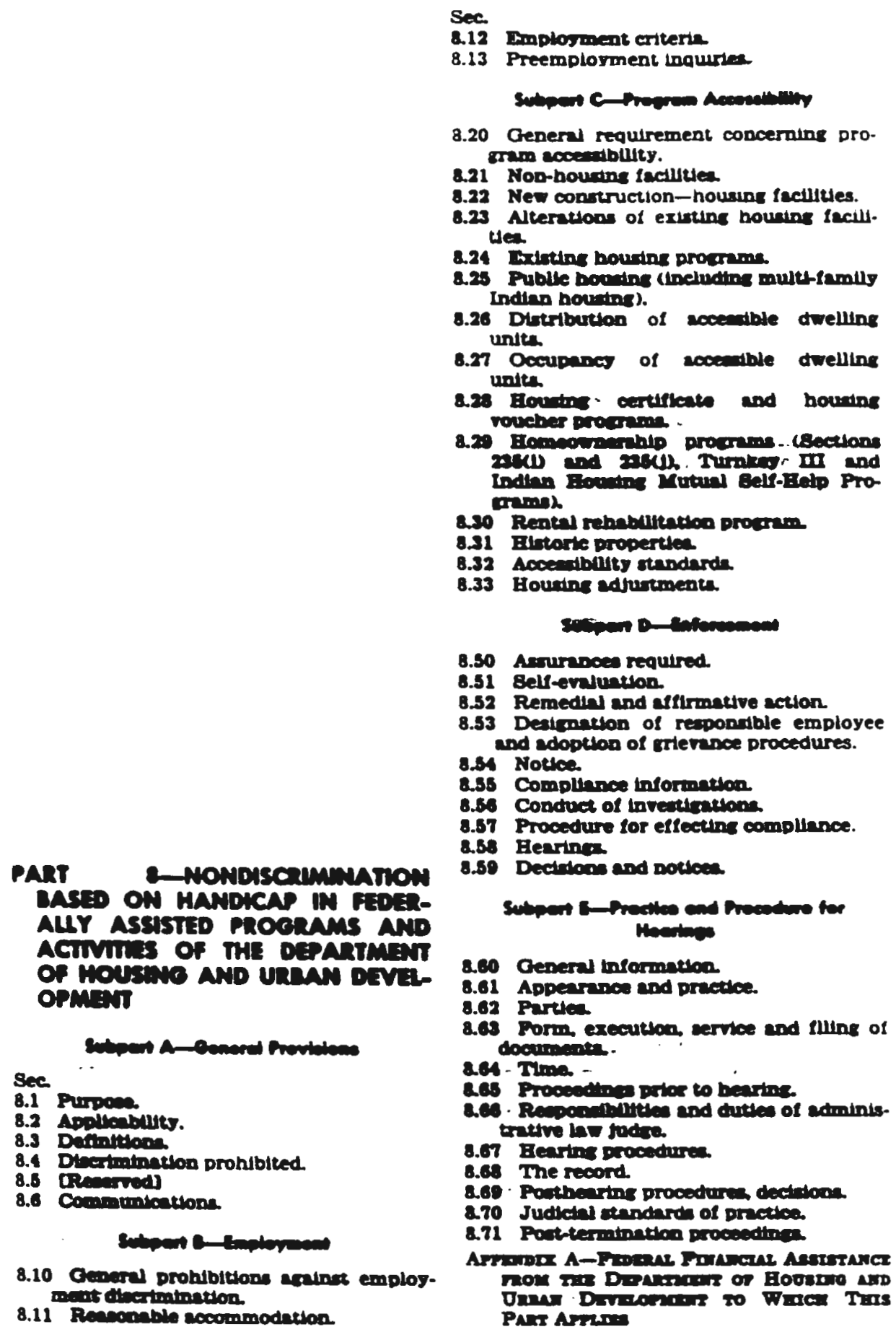


Sec.

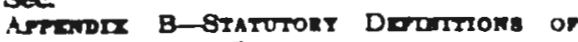
ENTDICarmo Peisons

Autzoners. Sec. 504 of the Reblbilitation Act of 1973 (29 U.S.C. 794): Sec. 109 of the idounine and Community Development Act of 1974 (42 U S.C. 5309). Bee 7(d) of the De perment of Eousing and Orban Development Act (42 U.8.C. 3536(d)).

Bounc 43 FR 20213. June 2, 1983, unleas ochernite noted.

\section{Subpert A-Gomeral Proviabens}

\section{Pripace.}

(s) The purpose of this part is to elfectunte rection 604 of the Rehbbilltetion Act of 1973, amended (20 0.8.C 791). to the end that no otherwise quilied individual with handicape in the Unted States atull, solely by reana of his or her bandicap. be excluded from the partictoution in be denled the beneflts of. or be subjected to discrimination under any protram or cetivity recelving Federal finnncial aratinance from the Deparment of Eousing and Drben Development. This part also implements section 109 of the Housing and Community Development Act of 1974, as amended (42 U.S.C. 5308). This part does not effectunte section 504 as it spplies to any promen or activity conducted by the Department. Complinnce with this pert does not ssoure complinnce with requirements for accessiblitty by physleally-handicapped person imposed under the Architectural Berriers Act of 1968 ( 42 O.S.C. 4151-1157; 24 CFR Part 40).

(b) The polledes and standurds for compliance established by this part are established in contempintion of and with i view to enforcement throuch, the Departanent's edminit. tration of protrmm or sctivities re celving Federal finnotal andetence and the edminttretive procedure de cribed in Bubpert D and $\mathrm{E}$ (includlng. without limitation, judiclal en forcement under \$ 8.67(a)).

\section{Appllaballity.}

This part applies to all applleants for. and recipients of. BUD seaintence in. the operntion of protram or setivities receiving such endrtince. Buch ss artance includes, but in not limited to, that which is linted in Appendix $A$ of this part.

\subsection{Deftuitione}

As used in this part:

"Accesuble", when used with respect to the deaige, construction, or alteration of a freility or a portion of a factlity other then an individual dwellIn unith means that the fectilty or portion of the fectity oben deatrmed. constructed or sltered, can be spprosched entered and ured by indl.: vidunl with phrileal handicape. The phree "accesdble to and urable by" is ! synonomous with sccesidble.

"Acoentble", when used with respect to the detin. con truetion or viteratton of an thdividuel drelling unith. means that the unit is located on en soceratble route and when dedped, contaructed altered or adupted can be appronched, entered, and used by indi. viduals with physical handicaps. A unit that is on an sccesable route and is adaptable and otherwtse in compllance with the standard set forth in 8.32 is "sccesdble" within the meanins of this purasraph. When a unit in an extstins factlity which is beins mnde sccesdble is a result of alter. ation is intended for use by a spectifc qualified individus with handicaps (e.8. a current occupant of such unit or of another unit under the control of the eame reciplent. or an applicant on - witting (ist), the unit will be deemed sccenable if it meets the requirements of applicable tandards that addrees the particular disabillty or impairment of ruch person.

"Acce dble route" menn a continuous unobstructed peth connecting wa ceratble elements and spaces in bulldins or feclitity that complies with the sonce and resch requirements of applicable standinds presertbed by 1832 An sccentble route that rerve only socenthe units occupled by pen. sons with hearing or viaion impate ments need not comply with those re quirements intended to elfect sceent blitty for perion with mobtlity in. pairments.

"Adnptablity" means the abluty o" certain elements of a dwelling unt". such as Vitchen counters, sinks, and anb bers. to be added to, raised, lofi 
ired. or otherwise altered. to accommodste the needs of persons with or anthout handicaps. Or to accommodate ine needs of persons with different ijpes or degrees of aisabuty. For example, In a unit adsptable for a hearing-impared person. the wirung for insible emergency alarms may be installed but the alarms need not be in. stalled until such time as the unit is made ready for occupancy by a hearing-impatred person

"Alteration" means ang change in a faculty or its permanent fixtures or equipment. It includes, but is not limited to, remodeling, renovation, rehsbulltetion. reconstruction changes or rearrangements in structural pars and extreordinary repair. It does not include normal maintennee or repsirs. reroofing, interior decoration or changes to mechanical aystems.

Appllcant for assistance" means une who submils an epplication, request. plan, or statement required to be approved by a Department official or by a primary reciplent as a condi:ion of eligibility for Federal financial assistance. An application means such a request. plan or statement.

"Auxulary aids" means services or devices that enable persons with impaured sensory. manual. or speating skills to have an equal opportunity to participale in. and enjoy the benefits of. programs or activities receiving Federal financial assistance. For ex. ample, auxiliary aids for persons with impared vision may include readers, Brailled maceriais, audio recordings. and other sumilar services and devices. Auxiliary aids for persons with impaured hearng may unclude telephone handset amplifiers. telephones com. patible with hearing aids, telecommunication devices for devt persons (TDD's), Interpreters, notetakers, written matertals. and other similer services and devices.

"Department" or "HUD" means the Department of Housing and Urban Development.

"Frcillty" means all or anj portion of buildinges. structures. equipment. ioads. walts, parting lots, rollins stock or other real or persons property or interest in the property.

"Federal financtal asistance" means any assistance provided or otherwise made avallable by ithe Department inrough any grant. loan. contract or any other arrangement. in the form it:

(B) Funds:

(b) Services of Federal personnel: or

(c) Real or personal property or any interest in or use of sucn property. including.

(1) Trangfers or lesses of the proper. ty for less than faur market value or for reduced consideration: and

(2) Proceeds from a subsequent transfer or lease of the property if the Federal share of Its tair martet value is not returned $w$ the Federd Govern. ment.

"Federal finencial assistance" inciudes community developmenc funds in the form of proceeds from lowns gurmnteed under section 108 of the Housing and Community Development Act of 1974. as amended. but does not unclude assistance made avaulable through direct Federal procurement contracus or payments made under these contracts or any other contract. of insurance or guaranty.

"Handicap" means any condition or characteristlc that renders a person an tndividual with handicaps.

"Bistorlc preservation programs or activities" means programs or activities recelving Federal financial assist. ance that have preservation of historic propertles as a primary purpose.

"Historic properties" means those properties that are listed or are eligl. ble for listing in the National Register of Historic Places. or such properties designnted as histonc under a statute of the approprlate State or local gov. ernment body.

"Individual with handicaps" mens any person who has a phrsical or mental impairment that substantially limits one or more mujor life sctivities: has a record of such en imparment; or is regarded as having such an impair. ment. For purposes of employment. this term does not include: Ang individual who is an alcoholic or drug sbuser whose current use of alcohol or drugs prevents the Individual from performing the duties of the job in question. or whose employment. by resson of current alcohol or drug abuse, would constitute a direct threat to property or the safety of others; or 
to which Federal financiel assastance is extended. In the case of any other corporation. partnersnip. privace organiration or sole proprietorship; or

(d) Ang other entity which ts exablished by two or more of the entities described in paragrephs (b). (b). or (c) of this eection:

anj part of whlch is extended Federal finsnctel antance.

"Project" means the whole of one or more reatdenticl etructures and appurtenent structures. equipment, roedt, walten and partins lots whleh are copered by a ande contruct for Federd finenalal sedrence or application for assiatunce. or are treated is a vhole for procenting purposes. whether or not locuted on e common ate.

"Qunlifed individuel. with handlcaps" means.

(a) With respect to employment, an individual with handicaps who, with reasonable sccommodstion. can perform the ecsential functions of the job in question; and

(b) With respect to any non-employment prosram or activity whlch requires a person to perform services or to achieve a level of accomplishment. an individual with handicaps who meets the essentisl eligibility requirements and who can echleve the pur. pose of the program or activity without modifications in the prodrm or activity that the reciplent can demonstrate would result in a fundamental aleration in its nature: or

(c) With respect to ang other nonemplorment protenm or sctivits. an individual with handicaps who meeta the escentivl elifibility requirements for perticipation in. or recelpt of beav fits from that progres or sotvits. " Besentid ell dblity requiremdenter" thclude ctated ellobilits : reoutrumente such as income as well as other explis it or implicti requirements inberent in the nature of the prociam or sctivity. such as requirements that an cocument of multifumils housing be capable of meetins the reetpleat's selection eritetis and be capable of complying Fith all oblievtloes of occupanes vitur or Wthout supportive services - provlded by persons other than the rectplent Fot exnmple, a chronically motalls il Derson whose particular.. condtition poses a argificant rist of substantial
Interference with the safety or enfoyment of others or with his or her own health or safety in the aosence of neceasury supportive services ming be "qualified" tor occupancs in e project where such supportive services are provided by the reciplent. as part of the andited program. The person mny not be "qualifled" for a project lactins such services.

"Reciplent" means any state or Its political rubdividon, any intrumental. Ity of a Btate or tts polltical mubdiptdon any public or prtrate esency. instilution, orentwention, or other entity. or any pernon to which Federl thnnctal asdrunce is extended for en procran- co sctitity. Alrectly or through another redplent: includins ang wuccenor, andree, or trantere of a re chplent but excluding the ultimnte beneftctary of the essistance. An entity or person recelving housing asaistence pergments from \& reciolent on behnlf of ellofble familles under a housing sodistance parments procrum or a voucher prosman is not a recipl. ent or subredptent merely by virtue of recelpt of such peyments.

"Replacement cost of the completed feclitty" means the current cost of construction and equipment for a newly constructed housing faclilty of the size and type belne altered. Construction and equipment costs do not include the cot of land. demolltion. site improvements, non-dwellins isclll. ties and administrative costs for project development sctivitien.

"Securetary" mean the Bearetary of Bourtns and Urben Development.

"Section so4" mean section so4 of the Rebablittation Act of 1973, is

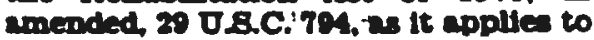
prounm or ectivities recetvin Feder-

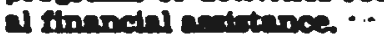

"Subtantial impatrment" means \& donifient loes of the interrity of in. Shed muterials deden quality, or specinl chnrecter resulting trom a perma. nent slterntion.

[53 FR 20233, June 2. 1985: 54 FR 8182, Feb. 27. 10002

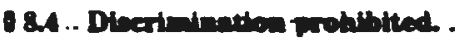

(s).. No qualified individual with hendicape ahall. solely on the bads of handicap, be excluded from partictpa- 
ang todividun who bas a currently contendous disense or infection and who. by ressan of such disease or in. lection. would constitute a direct threat to the health or safety of other individent or who. by reacon of the currently contegions disease or infecthon is unvble to perform the duties of the job. For purposes of other proancin and setittiten, the term does not tralude ans inditidual who is an slooholle or drus sbuser whose current use of scohol or drue prevents the individuel trom partetpating in the pro crem or ectivity in question, or whone partictpetion, by reason of such cur. rent alcobol or drue sbuse. would con. stitute a direct threat to property or the entet of otbar. As uned to this dertinttion the phrse:

(a) "Phrdicel or mentel impotrment" Includer

(1) Any phralolorteal disorder or condition. coemetic disfigurement, or inctomical lows affectins one or more of the followtar body systems Neuroloctent musculoateletis: specila rense orgens; resplratory, including speech orenne cardioveculer, reproductive: direstive: zenito-urinary, hemic and $15 \mathrm{mphatic}$ atdin: and endocrine, or

(2) Any mental or psyeholorical disorder. such 4 mental retardation. or. sanic braln syodrome, emotional or mental illness and specific learning dinablitter. The term "phytcul or mentel impeirment" includes but is not limited to, such diseases and condt. tloan se orthopedle visul speech and hearth impeirmente, cerebrel pelsy. autirm, epllepsy. muscular dystrophy. multiple sclerost cancer, heart difeara. divbetes - meatrl .. retardation. emottarel IInem; drus eddiction and Nooballon.

(b) "Yrior . life n catvitles". mean tunctores weh se earting for one's celf. performing manel tester welling. cedins, - beartuc. epeatine, breathine. leanthe and morting.

(c) "Ens a recond of weh an tmpairmant" mean bie a hitory of, or has been minclarifled as havins, s mental or phyical tonpatrment thet rubtan. thilly linte ore or more major life sot tritter. to s...

(d) "In recarded a havins en impeir. ment" means:
(1) Ens a phadical or mental lempatis? ment that does not substentially limit one or more major life activities but that is treated by a rectpient as consttution auch a limitution;

(2) Ene a phrited or mentel impatr ment that substantilly limits one or more majar life cetivities onis as : reault: of the.. eteltudes of other torerd rueh tmodtrment: or

(3) Eles noos af the tompirments of fined th parneraph $(\Omega)$ of this section but is treated by a rectplent as baring auch an tonptirneat.

"Mulutemils: houates probect" menos a project.containing five of mare drellite unlth

"Primar rodolant" means a peroca

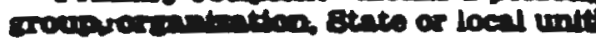
of coversent. that is enthorted or

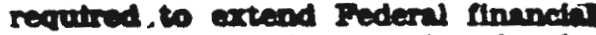
sedtance to enother reciplent for the purpose of carrying out a protram or activits.

"Propmen or cetivity" means all of the orerctions of:

(ax1) A departwent, asency, spectal purpose dirtalch or other instrumentulty of a state or of a local covern-? ment: or

(2) The entity of much state or lock sovernment that distributes such as. strtance and each such department or arewes (and each other stute or lochl govermment entity) to which the es artance th extended, in the cane of at distance to a Btate or locel sovernmente

(b)(1) A collese, univerdis, or other? porteoudary in titution, or e puble onters of bicher eduestion; or

(2) A Joen educationll agency (as doy

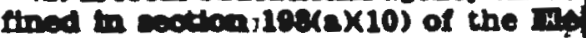
menting end Bocoeding Pducution As

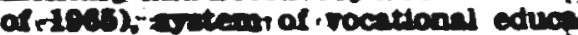
to pie ol

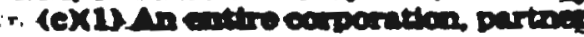

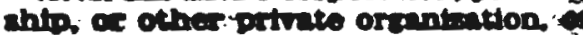
in enthe cole proprictorthto-

(1). Ilientinges to extended to rad

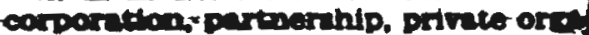
nt-itton or cole proprietorhip an whole or

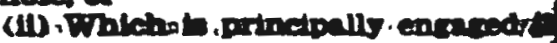

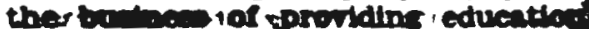

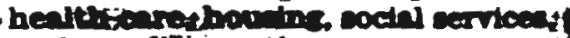

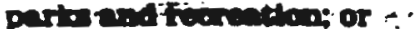

(2) The enthe plent or other comps rabla. 00 raphically separte facilis 
activity that recetves Federa flnincial assirtance from the Deparment or

(i1) Defeat or substantially impair ihe accomplishment of the objectives of the procram or sctivity with respect to quilified individuals with handlcape.

(6) As used in this section, the housing, aid, benefit, or service provided under a proctam or activity recelvin: Federal flnmpeid. ascistance thaludes any houvins, ald, benefit, or service provided in or through a fecillty that hes been constructed, altered, leased or rented, or otherwise scauired, in whole or in part. with Federel finenclal anatence.

(c)(1) Non-bnndicapped pernons mn be excluded trom the benatts of a program if the progen is limited by Federnd statute or executive order.to indsnduls with bendreape. 1 spectife clens of indifdunl with handicape may be excluded from a prosram if the prosram is limited by Federal statute or Executive order to a different clnss of individunls.

(2) Certuin Department proctams operate under statutory definitions of "handicapped person" that are more restrictive than the definition of "indi. vidual wth handicsps" contained in \$8.3 (see Appendix B). Those deflnttions are not auperseded or otherwise affected by this reculation.

(d) Recipients shnll administer pro gram and ectivities recelving Federal innocil salstance in the most intesrated settins appropriste to the needs of quilified individunls with handicaps.

(e) The oblimetion to comply with this part b not obviated or alleviated by ang state or local law or other re quirement that . besed on buodicap tonposes thcomedrent or contridictors probibltion or limits upon the ellethrity of quilified tndividunts with bandtcaps to recelve cervices or to practice sny occupstion or profession.

(f) The enumeration of spectife forms of prohiblted diseriminntion in parecreph (b) through (e) of thits eecton does not limit the senerel prohibtton in paregrob (s) of this section.

[S3 FR 20203, June 2, 1984; 83 FR 20115. July 26, 1989]

\section{5 [Reserved]}

\subsection{Commonications}

(a) The rectplent shall take appropriste steps to ensure effective communication with applleants beneficiaries, and members of the public.

(1) The reciplent abull furnish appropriste surditary alds where necessary to afford an individual with handicap in equal opportunity to partictpate in. and enjoy the benefits of. a proorm or sctivity recelving Federd flnancinl sodstance.

(i) In determining what euxdingy add are neceasery. the reaplent abnll ave primurs conddertion to the requeat of the todividur with handlcan :-

(ii) The redplent is not required to provide individunlly prescribed devices, reader for personal use or study, or other devices of a personal nature.

(2) Where a recipient communicates with applicants and benefictertes by telephone, telecommunication devices for deaf persons (TDD's) or equally effective communication systems shall be used.

(b) The reciplent shnll adopt and implement procedures wo ensure that interested persons (including persons with impaired vision or hearing) can obtain information concerning the existence and location of sccesalble serv. lces sctivitien and fecllitien.

(c) This section does not require a reciplent to take ans sction that the reciplent can demonstrate would result in a fundemental elterntion in the nature of 8 prodram or ectivity or In undue finnmeinl and edminitarntive burdear - If an ection would realt in wab on elterntion or burden, the reclplent abll tate an other setion that would not result in such an slterattan or such burdens but would nevertheleat ensure that to the marimum extent - posible, Individunis with hondicap recelve the benefits, and services of the progrm or scuvity recelotns BUD asdance. 
Subpart : Enplernom ..:

8.10 Genern prohibttion ageint em ploymeat diseriminumon.

(8) No qualified individual with hendicape shell, solely on the berts of handicap, be subjected to diserimtins tion in employment under ang pro grem or activity that recelves Federal tinnneil asdrance from the Depart ment.

(b) A reciptent mas not limith secresete, or classify applleants or employees in any way thit adversely sefect. their opportunities or status becense of hendicap.

(c) The problbition asinst discrimlantion in employment applies to the following ectritie-

(1) Recruttment sodvertidns, and the procesating of spplication for emplorment:

(2) Biring, upgrading, promotion. arvand of tenure, demotion, transier. Lgofl. termination, right of return trom layolf, injury or llinese and re hiring.

(3) Rates of pay or any other form of compensation and changes in com. Densetion:

(4) Job assignments, Job classificaLlons orcanizational structures, podtion descriptions, lines of progresedon. and seniority lists:

(5) Leaves of absence, sick leave, or any other leave:

(6) Fringe benefits spllable by virtue of employment. whether or not sdministered by the rectplent:

(7) Selection and financial support for training. Including apprenticeship. profesalonal meetines conferences. and other related sctivities and selection for lesves of absence for tratinins.

(8) Employer eponsored ectivitiea, including socill or recreational proarmos and

(9) Any other term conditan or privilege of employment.

(d) A redplent mas not partidpate in a contrectind or other relationship that bas the effect of subjecting guallthed appliennte with handicaps or em. ployees with handlape to discrimina. tion prohlbited by this aubpart. The relationahipe referred to in this pare. anph (d) inciude relationship with employment and referrel segender. labor unions, orcentections providins or administerlng tringe benefits to employee of the reciplent. and orcentren tions providing tratining and appren-? ulceship programs.

8.11 Reomonwile coconnodation.

(a) A rectplent shall mire reasonsble sccommodation to the known phydeal or mentel limitations of an othertwe quilified applicant with bundteape or employee with hand. cape. unless the rectplent on deman. Arate that the eccommodation would impose an undue bardship on the operition of its promem.

(b) Reanonble scoommodation mav include:

(1) Matur trellitie uned by emplos. ees econdie to and unble by indiv't unls with heodionpen and

(2) Job restroctaring, job relocetich part-tine or modifled wort schedulear acquidtions or modification of equip. ment or devices, the provituon of readers or interpreters, and other atmiln settions.

(c) In determining, under parngraph (a) of this section, whether an sccommodation would impose an undue hardahlp on the operation of a reciplent's procrum, factors to be considered include:

(1) The overall size of the rectplent's prostem with respect to number of employees. number and type of faclltien and dre of budget:

(2) The type of the rectplent's opers ation. Including the composition and structure of the reclplent's wortitorce and

(3) The nature and cost of the it commodtution needed.

(d) A rectplent mag not deny an emplosment opportunity to s quillec hundtespoed emplogee or applientit. the bets lor the dental is the neodit

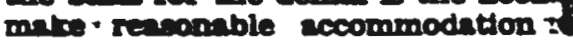
the phrical or mental limitations the employee or appllant.

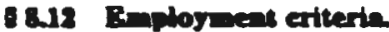

(a) A redplent mag not use any of plosmeat tent or other selection art Hor 'that-cercens out or tend:? ccreer-out' indtriduais with handic or ans elareof individuals with ban. con unleers 
(1) The recipient demonstrates that the test score or other selection criterion. as used by the recipient. is job-related for the position in question: and

(2) The approprate HUD offictal demonstrates that aternative job-related tests or criteris that tend to screen out fewer individuals with handicape are unavalinble.

(b) A reciplent shall select and administer tests concerning employment w envure thath when administered to an spplicant or employee who has a handicap that impairs sensory. manuly or spesing sillis, the test re sults sccurately renect the applicant:s or emplogee's job stllis aptitude. or whetever other factor the teat purports to measure, rather than the applicent's or employee's impaired sensory. manunl or spearing atills cexcept where those stills are the factors that the test purports to mesure).

\subsection{Preenployment inquititea.}

(a) Esxcept as provided in paragraphs (b) and (c) of this section. a recipient may not make a preemployment inquiry or conduct a preemployment medied examination of an applicant to determine whether the applicant is an individual with handicaps or the nature or severity of a handicap. A reclplent may, however, mate preemployment inquiry into an applicant's ablilty to perform Job-related functions.

(b) When a reciptent is undertaking affirmative action efforts, voluntary or otherwise. the reciptent may invite sppliennts for employment to indicate whether and to what extent they are handicapped, If the following conditions are met:

(1) The reciplent stated clearly on any written questionnaire used for this purpose, or makes clear ordily if no written questionnalre is used, thet the information requested is intended for use colels in connection with its remedial sction obligution, or Its voluntary or effirmative ection efforta and

(2) The reciplent states clearly that the information is betns requested on a volunting basis, that it will be kept conildentill (as provided in paragreph (d) of this section). thet refusal to provide the informetion will not subject the applicant or employee to ang ad- verse treatment. and that the intormation will be used only in accordance with this part.

(c) Nothing in this sectuon shall prohibit a reciplent from conditioning an offer of employment on the results of a medical examination conaucted before the employee's entrance on duty if all entering employees in that category of job classification must take such in examination regardless of handicap. and the results of such examination are used only in accordance with the requirements of this part.

(d) Informntion obtained under this section concerning the medieal condition or blstory of the spplienat is to be collected and maintained on separnte forms that are accorded confidential. ity as medied records. except thet:

(1) Supervisors and manager may be informed of restrictions on the wort or duties of individunis with handicaps and informed of necessary accommodetions:

(2) Furst aid and safety personnel may be informed if the condition might require emergency treatment: and

(3) Government offlcials investigating compliance with section 504 shall be provided relevant information upon request.

Subport C-Proprow Acessubsilly

88.20 General requirement concerning program acceacibility.

Except as otherwise provided in $858.21(\mathrm{c})(1), 8.24(\mathrm{~s}), 8.25$, and 8.31, no qualifled individual with handicaps shall. because \& recipient's fectlities are insocesalble to or unusable by individunis with handicapa be denled the benefits of. be excluded from particl. pation in or otherwise be subjected to discriminntion under any prosrum or sctivits thet recelves Federl Innnal enditence.

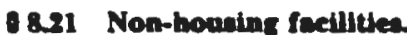

(a) New construction. New non-hous. in facllities ahall be destened and constructed to be readily sccessible to and usable by individuals with handicaps.

(b) Alteretions to focilities Alter. ations to extsting non-housing feclll. 
tles shall, to the maxins extent fesilble. be made to be reanity acceasuble to and usable by romotunis with handicaps. For purpoea 1 this para3raph. the phrase "to te: maximum extent feasible" shall no ite interpret ed as requiring that a ratint make a non-housing facllity, ar berent thereof. accessible if doing a would tmpose undue financial and menteturive burden on the operatiear the rectolent's procrum or activis.

(c) Existing non-howno fecilities. (1) Generd A reciplenstinll operate each non-housing prosich or activity recelving Federal finnow intance 80 that the procrmm oradoits. when viewed in its entirety, if resdily secesslbie to and useble by atfidunl with handicape. This paraes ta does not

(1) Necenarly require seciptent to make each of Its existhentow houning iscullties sccessible to and usuble by individuels with handing:

(11) In the case of tortc preservation programs or activitiny require the reciplent to take ary retion that would result in a sumentiv impair. ment of significant htowric festures of an historic property;

(iii) Require a recipian to take any action that it can demumare woukd result in a fundamentalivibation in the asture of its prosen or sctity or in undue finsacielard administra. tive burdens. If an seten. Fould result in such an alteration 6 anch burdens. the recipient shall tate vaz action that would not result 3 ereh an alter. ation or such burder tout would nevertheless ensure that antiduals with handicaps receive twi tenefits and

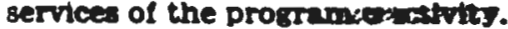

(2) Methods.-(1) Giserat. A recipient may comply with tis requirements of this section in ttr gastrims and sctivities receiving Fedter ftonncial as. sirtence through such teane as loces

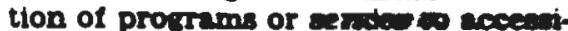
ble fecllities or scceritie portions of facilities, assiconment addes to benefleivies, home visita the addition. or redesics of equipment to spoliances or furnitbiars) chan a mares: ment policies or preisures equitatLion or construction at sdditional is. cllities, or siterntions a exterine 1seill. ties on a selective ber on orher methods that result in Javiog its pro- rmam or activity accessible to individuais with handicaps. A recipient is not required to make structural changes in existing facilities where other methods are effective in acnieving compliance with this secuon. in choosing among available methods for meeting the requirements of this section. the reciplent snall give prority to those methods that offer prostams and ac tivities to qualified Individuals with handion in the most integreted set ting approprinte.

(ii) Fistoric preservation program or actioities. In meeting the requirements of $\$ 8.21(c)$ in historic preserve tion prosrams or activities, a reedplent shall give priority to methods thet provide phrated scoes to individurls whb hindicape. In cases where phy icel altankion to an historic properts is not required because of: $8.21(\mathrm{c})(1)$ (II) or (III). alternative methods of achieving prosram scceastbillty include using sudio-visual meterals and device to depict those portions of an historic property that cannot otherwnse be made accessible: assigning persons to guide individual of with handicaps tnto or through portions of historic properties that cannot i otherwise: be made accessible; or adopting other innovative methods.

(3) Time period for complience. The rectpient shall comply with the oblightions established under this section within sixty days of July 11. 1988. escept that where structural changes in ficlities are undertaken. such changes shall be made within three years of July 11,1988 , but in any event as expeditiously as possible.

(4) Transilion plan. If structurn changes. to non-housing facilltes win be undertaken to achieve prosram as cerablilty. a reciplent shall develog within to monchs of July 11, 1988, trandition pling setting forth the step necurarg to complete such changea The ping shall be developed with the asintance of interested persons includine individuals with handicape or orsenizattons represencing individual with handicape. A copy of the trants thon pian ahall be made available fo: publle inspection. The plan shall, at minimum-

(1) Identify physical obstecles in the. reeipient's facilities that limit the ac 
tion in. be denied the benefits of. or otherise be subjected to dtrertmion ison under ang prostam or activity

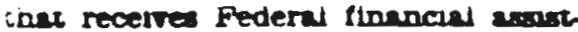
ance trom the Department.

(b) (1) A reaplent in providing ang hourthe. ald benefith or service in proarem or sctivity that receives Federal tinandel axitunce from the Department mas not directly or throurch contructurl licenaing. or other ar. rancements solely on the bads of bandleas:

(1) Dens a quilfied individuel with hendicape the opportunity to particl. pate in, or benefit Irom, the houaing. aid. benetth or service:

(i) Aftand s qunllied individual rith bnedicare un opportunity to partictpete in or benafle from, the hourths. ald benetth or service that is nol equal to that aflorded to others:

ili) Protide a quilifed individual With handicase with any housing, ald. bepefit, or service that ts not as effective in affording the individual in equal opportunity to obtaln the anme result to min the same benefit, or to resch the same level of achlevement as that provided to others;

(Iv) Provide different or separate housins. sud, benefits, or services to individuals with handicaps or to ang class of individuals with handicaps from that provided to others unless such ection is necessary to provide qunlifled individuals with hendicaps with housing, ald benefits, or services that are as effective as those pronded to othere

(v) Ald or perpetunte discrimination ageinst a qualified individual with andicape by providing afconificent assistance to en soency, orgentrotion or person that discriminste on the bats of hendieap in providing any houring. ald beneft or exvice to benefinte in the reclpient's federally axdred prodram or ectivity

(vi) Dens a qunlified indifdual with bandleap the opportunity to participate as a member of plennins or advisors boards

(vil) Deny a dwelling to an otherwise qualified buyer or renter becaure of handicap of that buyer or renter or pereon redidins in or intendins and ellGble to reside in that drelling after it is sold, rented or made svallable; or (vili) Otherwse limit aulifled in- . dividul with handicape in the enjor. ment of any Hght privlere, sdvantege. or opportunity enjoyed by other. quallifed lodividuals recelving the houning, ald benefith or service.

(2) For purposes of this part hourst ing. aids benefits, and services, to be: equilly effective. are not required ta. produce the identical result or level of achlevement. for individunle with-1 handicaps and non-handicapoed peret sans, bue must afford tndividuals with handleape equel opportunity to obtatn the anme reault, to gan the anme beneflth. or to reach the enme level of schievement.

(3) A rectolent mas not dens o quilh tled individuid with handicape the $0 \%$ portamits to Drtidpace in ens lederi? if ectuted procesm or setivity that if not separnie or different despite the exdrtence of permissibly seperste ar different programs or ectivitles.

(4) In any procram or activity recetos ins Federl finnncil assistance from the Department. a recipient mny not: directly or through contrectul or other arrangements utilize critert or methods of admintstration the pur. pose or effect of which would:

(1) Subject quallified individuals with handicape to discrimination solely on the banis of tandicap:

(ii) Defeet or substantially impaty the scomplishment of the objective of the reciplent's federally sedrted procerm or activity for quelified indt viduals with a particular bandicap ton rolved in the promm or sctirtity unies the reciplent an demonstrater that the criterts or methods of edmin intretion are manifestly related to the cocomplinhment of an objective of : proarm ar activity. or (iii) Pexpotente the dtserimination.' ancther 'rectiptent is both rectplen. se subject to comman administratif control or are erenctes of the am State.

(5) In determining the site or 10 ch tian of a tederally adred lscilitg applicant for asatrance. or a rectplmos not mate selections the purper or effect of which would:

(1) Irelude quallfied indivduals of herdicap trom dens them the bon fits of, or otherwise subject them si discriminution under, any prosram. 
ressibluty of tis programs or activities to Indifiduals ath handicaps:

(i) Describe un detajls the methods - hat will be used to make the facillties icessible;

ii) Specify the scnedule for laking the steps necessary to achieve compliance with this section and, if the tume period of the transition plan is longer than one gear. identify steps that will be taken during each year of the transition period:

(iv) Indicate the offlcial responsible for implementation of the plan: and

(v) Identify the persons or Broups with whose assistance the plan was prepared.

:53 FR 30233. Juse 2. 1988: 53 FR 28115. نulg 26. 1988]

Emxtrv DATE Notr At 53 F'R 20233. June 2. 1988. 8.21 was added. Paragraph (c)(4) contains information collection requirements that have been submitted for approval by the Otflce ol Maragement and Judget. It is not elfective untu OMB aporoval has been oblauned and the public noifled to that effect through a lechnuca amendment to this section.

\$8.22 New Construetion-housing facilitien.

(a) New multiamily housing projects (including public housing projects as required by 8.25 ) shall be designed and constructed to be readily accessible to and usable by individuals with handicaps.

(b) Subject to paragraph (c) of this section a minimum of five percent of the cotal dwelling units or at least one unit in a multiamily housing project. Whichever is greacer, shall be made accessible for persons with mobility im. fairments. A unit that is on an accessi. ble route and is adsptable and otherwise in compliance with the standards set forth in $\$ 8.32$ is accessible for purposes of this section An additional $t$ wo percent of the units (but not less than one unit) in such a project shall be accesdble for persons with hearing or vision impairments.

(c) EUD may prescribe a hicher percentase or number than that prescribed in parasreph (b) of this section for ang area upon request therefor by any effected rectplent or by ang State or local covernment or agency thereof based upon demonstration to the res. sonable satisfaction of HUD of a need for a mugher percentage or number. Dased on census daca or other avall able current dsta inciuding a current y effective Housing Assistance P!an or Comprehensive Homeless Assistance Plan), or in response wo evidence of a need for a higher percentage or number received in any other manner. In reviewing such request or otherwise asseaving the existence of such needs. HUD shall take into account the expected needs of eliglble persons with and without handicaps.

8 8.23 Alterations of existing housing faeilitiea.

(a) Substantial alteration If alterations are undertaken to a project (1n. cluding a public housing project as required by $8.25(8)(2)$ ) that has 15 or more units and the cost of the alter. ations is 75 percent or more of the replacement cost of the completed tacili. ty, then the provisions of 8.22 shall apply.

(b) Other alteracions. (1) Subject to paragraph $(b)(2)$ of this section. alter. ations to dwelling units in a multifam. ily housing project (including public housing) shall. to the maximum extent feasible, be made to be readily accessible to and usable by individuals with handicaps. If alterations of single elements or spaces of a dwelling unt. when considered together. amount to an alteration of a dwelling unst. the entire dwelling unit shall be made ac. cessible. Once five percent of the dwelling units in a project are resdily accessible to and usable by undividuais with mobllity impairments, then no additional elements of dwelling units. or entire dwelling units, are required to be accessible under this paragraph Alterations to common areas or parts of feclities that affect accessibllity of existing housing facllities shall. to the maximum extent feasible. be made to be accesatble to and usable by individ. uals with handicaps. For purposes of this paragraph, the phrase "to the madmum extent feasible" shall not be incerpreted as requiring that a reciplent (including a PHA) make a dwelling unit common area facllty or element thereof accessible if doing so pould impose undue financial and adminis. 
irative burdens on the operation of the multirally bousung project.

(2) HUD mny prescribe a higher percentage or number ihan that pre scribed in paractapn (b)(1) of this sectlon for ang are upon request therefor by any affected recipient or by any State or local covernment or agency thereot based upon demonstaration to the reasonable atidection of HUD of a need tor a bilgher percentuge or number. based on cenvus date or other avallable current data (including a currently effective Bousing Astrance Plan or Comprehensive Bomeless Asstutance Planl. or In respone to ertdence of a need for a hirher percent age or number recelved in any other manner. In reviewing such request or otherwise anewing the extrtence of such Deeds, EUD shall tate into account the expected needs of ellatble persons with and without handtcaps.

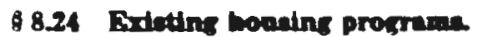

(a) General A reciptent shall operate each exirting housing procram or activity receiving Federd finsnctal sssistance 80 that the procrum or activity, when viewed in its entirety, is readIfy acceastble to and usable by individuals with handlcaps. Thts paregreph does not-

(1) Neceacarily require a reciplent to make each of its existing tectilties accessible to and usable by individuals with handicaper

(2) Require a reciptent to take ang sction that it can demoristrete would result in a fundamental alteration in the nnture of Its procram or setdrits or in undue financial and edministre. tive burdens if an action would result in such an alteration or such burdems. the rectplent ahall tate ans setion that would not reail in woch in elter. stion or such burden but woald nevertheles eosure that indivituls ofth handicape recelve the benefts and services of the procorm or sotivits.

(b) Methode A rectpient mny comply with the requitements of this eection throurth wich mean as reantmment of service to sccesdble bulldines is siemment of aides to bendictirte- proFidon of houthe or related envices at

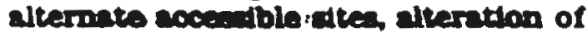
exirtins inclittles and construction of new frellities or ang other methods thet result in maving its prosem or activities readily sccesable to and isable by indifiduals with handicapas A reciplent is not required to make structurat changes in existing houdar fectltiles where other methods are eff fective in acnieving compllance with this section or to provide supportive services that are not part of the pro gram. In choosine amons evellabl methods for meeting the requirement of this section. Cne rectplent thall tre priority to those methods that offer progrems and sctivities to qualified th. dividuals with bandicaps in the mos incerseted setting spproprinte.

(c) Time pernod for compliance Th reciplent ahnil comply with the obli? tions extablished under this sectid. whin atriy dage of July 11, 19:

(1) In a public housing procre? where structural changes in faclitted are undertaten, such changes shall be made within the timeframes exth. Ushed in $8.25(\mathrm{c})$.

(2) In other houstng programi where structurat chenges in factition are undertaken. such changes shall be made within three years of July 11 . 1988. but in ang event as expeditiounly, as posedble.

(d) Trenvition plan and time period for structural changes. Bxcept as provided in $18.25(\mathrm{c})$, in the event this. structural changes to faclities will be undertaken to achleve progrmm acen sibility. \& rectplent shall develos withln dx months of July 11. 1982. transtion plen setting forth the step necenary to complete such chnng The plan thall be developed with th? asalance of intereated persons if. cludine Individuris with handicapes. orrentrations reprewenting individe? Fith handicape A cops of the trat ton plen chull be mede evellablen? public inspection. The plen anall, mintmum -

(1) Identify phydeal obstacles to th reciplent's facllities that limit the

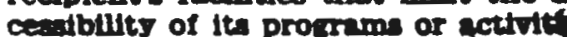
to individun . Fth handicaps..... it

(2) Deseribe in detall the meth. that will be used to mate the frollu: iccestbles

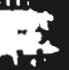

(3) Bpecify the schedule for tait the tep neceasery to schleve coms. ence with this section and, if the th. 
pertod of the transition plan is longes than one gear. Identify steps that wull be taken during each year of the tranittion pertod:

4) Indicate the official responsible for implemencacion of the plan: and

(5) Identify the persons or sroups with whose assistance the plan was prepared.

(33 FR 20233. June 2. 1988; 53 FR 28115. July 26. 1988)

Emectre DATE NOTE At 33 FR 20233 June 2. 1988. 8.24 mas eaded Farvarnot (d) containg informstion collection require ments that have been suamitled tor spprov. a by the Office of Mancement and Budret It is not effectire untll OMB approvel has been obtained and the public noiried to that effect throush a technien imendinent to this section.

8.25 Puble hovatn (tneloding muld. femily Indien housing).

(8) Development and alteration of public houring. (1) The requirements of 8.22 shall apply to all newly constructed public houstag.

(2) The requirements of 8.23 shall apply to public housing developed through rehabllitation and to the alteration of publlc housing.

(3) In developing public housing through the purchase of existing properties PHAs shall give priority to taculties which are readily accessible w and usable by tndividuals with handi. caps.

(b) Extsting public housing-oeneral The requirements of $8.24(\mathrm{~s})$ shall apply to public housthe programs.

(c) Existing public hourino-needs essesament and trarsition plan As soon as passtble. each PEA shall sssess, on a PHA-wide bests the need of current tensits and applicants on Its wattins list for sccesible units and the extent to which such need have not been met or cannot resonnbly be met withto four years through devel. opment, viterations otherwtee contem. plated, or other progrems adminisiered by the PEA (e.8. Section 8 Moderate Rehnbilitation or Section $8 \mathrm{Bx}$ Lting Boustine or Bousine Vouchers). If the PRA currently has no acceodble units or If the PHA or HUD determines that information reserding the spullablitty of eccecodble units hes not been communicated sufficlently so that as a result. the number of elloi. ble qualified indivduals with hand. caps on the waiting list is rot falrly -epresentative of the number of sucn persons in the area the PHA's assess. ment shall include the needs of eligible quallied individuals with handi. caps in the aree If the PHA deter. mines, on the bssis of such sasess. ment that there is no need for addi. tions scceatble dwelling units or that the need is beins or will be met withln four years throurg other meand such ss new construction, Bection 8 or alter. atjons otherwise contemplated. no fur. ther action ts required by the PHA under thls parneraph. If the PEA determines on the bexh of its need ig. seament. thet alterutions to mate additional units sccentible must be mide so that the needs of ellichble quallfted Individuals with handicape may be ac. commodated proportionally to the needs of non-handleapped individuals in the same caterories, then the PRA shall develop a transtion plan to achleve procram accesstbillty. The PEA shall complete the needs aseasment and transition plen. If one is necessary. as expeditiously as possible. but In any event no later than two gears after July 11. 1988. The PHA shall complete structural changes necessary to achleve proerrum accessiblilty as soon as posalble but in any event no later than four years after July 11. 1988. The Amintant Secretary for Fair Housing and Equal Opportunity and the Assistant Secretary for Puble and Indian Bousine may extend the four gear pertod for a pertod not to exceed two years, on a casc-by-case determl. nation that complinnce within that pertod would impose undue inancial and sdministrative burdens on the operntion of the rectplent's public hous. Ine procram. The-Eecretary or the Underseareters ming further extend this time pertod in extroordinary circum. stances. for a period not to exceed one year. The plan shall be developed with the ensirtance of interested persons including individuals with handicaps or orsanifstions representine individuals with handicapa A copy of the needs asseasment and trandtion pian shall be made avilinble for public inspector. The trandtion plen shall, at a minimum- 
(1) Identify physical obrucles in the PFA's facllities ie.g., dweling units and common areas) that knit the ac. cessubllty of its program or activities to individuals with handicap:

(2) Describe in detall be methods that will be used to make the PEA's facllitles accesatble. A Fan may, If necesenry. provide in its plen that it will seek HUD approval, under 24 CFR Part 868, of a comprehenge modernization proctram to meet the needs of ellotble individuals with bualieape:

(3) Specify the scheduie for turing the stepa necesang to schieve compliance with this section and If the time of the transtion plen is ivinis than one gear. Identify steps will be taten durting each gear of the trandition pertod:

(4) Indlate the officid responsible for implementation of the plan: and

(5) Identlfy the persans or groups with whose assistance ith plan was prepared.

Emective DATE Notr At 23 FR 20233 June 2. 1088, 8.25 was saded Peregroph (c) contain informulion collection separre ments that have been subminted for approv a by the Office of Mmacement and Budret It is not effective mull OMB ap proval has been obteined and the public notifled to that effect through s technical amendment 10 this section.

8.26 Distribution of accomble drellins unite.

Accessible dwelling units manised by 8.22, 8.23, 8.24 or 8.25 smadl. to the mardmum extent fessible and subject to rensonable heajth and safety requirements, be distributed throughout projects and altes and shrd to srillable in a sufticient range or niter and amenitice so that a quined indriddual with handicaps' choic of living ar. rancrements is. is o whote comparble to that of other persons the for houding asdrtance under the enme program. Thls proviston shell not be construed to require proviton of an elevator in any multianits housing project solely for the purrise of permitting location of sccentse units above or below the sccusuble stede level.
8827 Occupancy of accesubte dretling unite.

(a) Owners and managers of multl. family housing projects having accesslble units shall adopt sultable means to assure that information regarding the avalinblitig of accessible units reaches elleible individuals with handicaps. and shall tate reasonable nondiscrim. Inatory steps to maximize the utllizstion of such units by eligible individ. unils whose disablity requires the accesabilits features of the particular unit. To this end, when an sccesstble unit becomes vecunt the owner or mennger before offering such units to a non-handleapped applicant shall offer sech unit:

(1) First to a current occupant of another unit of the same project, of comparable projects under common control. havins handicaps requiring the sccestblitty features of the vacant unit and occupytag a unit not having such teatures, or, If no such occupant exists, then

(2) Second to an eligible quallited applicent on the waiting list having a handicap requiring the accessibility features of the vacant unit.

(b) When offering an accessible unit to an applicant not having handicaps requiring the accessiblitty features of the untt, the owner or manager may require the applicant to agree (and may incorporace this agreement in the lease) to move to a non-eccessible unit when avallabie.

88.28 Houning certificate and housing roucher programs.

(a) In carrying out the requirements of this aubpart a reciptent edministering section 8. Dristing Housing Cer. tifleate-proctam or a housing voucher prosrm annil:

(1) In providing notice of the avallsblilty and nature of housing assist ance for lower-income families under prosiam requirements, adopt suttable menns to assure that the notice reache elipdile individuals with hendicenpe

(2) In ite sctivitites to encourage par. ticlpetion by owners. Include encour. agement of participation by owners having accessible units: 
(3) When istuing a Housing Certifl. cale or Bounns Voucher to a iamily thich includes an individual with handicaps include a current usting of availeble sccessible unuts tnown to the PEA and if necessary. Otherwise suaist the tamily in locating an availuble sccestble dwelling unit:

(4) Take into account the spectal problem of sbility to locate en sccesalble unit when considerine request by elldble individurls with handicape for extendons of Bousing Certificates or Houning Vouchers; and

(5) If necesenry in order to schleve complinnce with this subpart request under 24 CFR Part 882, an exception to the Fatr Market Rents to sllow sectlon 8 certifleste holdere to rent sccess sible uaits.

(b) In order to ensure that particl. patins owners do not discriminate in the recipient's lederally assisted program. recipient shall enter into 8 HUD-epproved contract with perticlpatins owners, which contrect shall include necesary assurnaces of nondiscrumination.

\$ 8.29 Homeownership program (Sections 235(1) and 235(j). Turnkey III and Indian Houning Mutual Self-Pelp prostame.

Any housing units newly constructed or rehablltated for purchase or single family (including semi-attached and attached) units to be constructed or rehebllitated in a procarm or activity receiving Federal finncial asoirtance shall be made scceasible upon request of the prospective buger if the nature of the nandicap of an expected occupant $s 0$ requires In such case the buger shell consult with the seller or bullder/sponsor regarding the opectic dedin fenture to be provided If sccesibluty fectures-celected is the option of the bomebuyer are ones cov. ered by the standurds presurbed by 8 8.32. those fenture shall comply with the scandard prescribed in 8 8.32. The buser shall be permitted to depart from particular spectileations of these atandards in order to sccom. modate his or her specific handicap. The cost of mitins a fectilits sccessdble under this parngraph mey be included in the mortere emount within the cllowable mortenge limits, where applicable. To the extent such casts exceed allownole morrgage limits, they may be passed on to the prospective comebuyer. suoject to maximum saes price limulsuons (see 24 CF'R 235.320.)

88.30 Rentel rehabilitetion prosrem.

Each Brantee or state reciplent in the rental rehablutation procram shall. subject to the priority in 24 CFR $511.10(1)$ and in accordnnce with other requirements in 24 CFR Part 811, give priority to the selection of projects that will result in dwelling units beins made readlly eccesable to and usable by individualn with bandicaps.

[53 PR 20233. June 2 1988; 53 FR 28115. Jul 26. 18881

\section{8si Hidtark propentien}

If bistoric properties become subject to alterations to which this par appites the requirements of 4.1 .7 of the standards of 8.32 of this part shall appiy, except in the case of the Urban Development Action Grant (UDAG) prostam In the UDAG prostam the requirements of 36 CFR Fart 801 shall apply. Accesalblilty to historic proper. ties subject to alterations need not be provided if such accesstbiltty would substantivily impair the significant histonc features of the property or result in undue finsncial and adminis. trative burdens.

\subsection{Accearibility atandarde.}

(a) Effective as of July 11. 1988. deston consuruction. or altericion of building in conformince with sections 3-8 of the Uniform Federal Accessibllitg Btendards (UFAS) (Appendix $A$ to 41 CFR Bubpart 101-19.6 for generaltype butlding and appendix $A$ to 24 CFR Bubpart 40 for realdentill struc. tures) ahlil be deemed to comply with the requirements of $858.21,8.22,8.23$. and 8.25 with respect to those bulld. inge Departures from particular technical and scopins requirements of UPAS by the use of other methods are permitted where mbstantially equivs. lent or greater access to and usabluty of the butlding is provided. The alteratson of houring fectlities shill also be in conformance with additional scoping requirements contalned in this part 
(b) For purposes of this section. sec. tion 4.1.6(1)(s) of UFAS ghall be incerpreted to exempt from the requirements of UFAS only mechanucal rooms and other spaces that. because of their intended use. Will not require sccessiblitty to the public or benefletaries or result in the emplogment or realdence theretn of individuals with phydel handleape

(c) Thts section does not require reclptents to mate buildins slterntions that have little likelihood of being ac. complinhed without removing or alter. ing a load-beanos structural member.

(d) For purposes of this section. section 4.1.4(11) of UFAS may not be used to walve or lower the mintmum of flve percent scceadble units required by $8.22(b)$ or to apply the minimum only 10 projects of 15 or more dwelling units.

(e) Except as otherwitse provided in this paracraph. the provisions of 88.21 (a) and (b). 8.22 (a) and (b). 8.23. 8.25(a) (1) and (2), and 8.29 shail apply to facullties that are designed. constructed or altered after July 11. 1988. If the design of a facillty was commenced before July 11, 1988. the provisions shall be followed to the maximum extent practicable. as determined by the Department. For purposes of this parastaph. the date a $1 \mathrm{a}$ cillty is constructed or altered shall be deemed $t o$ be the date bids for the construction or alteration of the facill. ty are solicited. For purposes of the Urban Development Action Grant (UDAG) proanm, the provtsions ahell appiy to the construction or alterntion of faclilitie that are funded under applications submitted after July 11. 1988. If the UDAO application wes submitted before July 11, 1988, the provtatons ahnll apply, to the mnadmum ertent preticable. as determined by the Department.

\section{Bosatas adjutmeate.}

A reciplent shall modify its housing policies and prectices to ensure that these pollctes and practices do not discriminate, on the basis of handicap. against a qualifted individual with handicaps. The rectplent may not impose upon individuals with handicaps other pollctes. such as the prontbition of assistive devices. auxiliary alarms, or guides in housing facluties. that have the effect of libiting the participacion of tenants with nandicaps in the rectpient's federally assusted houstne prosram or activity in violation of this parh Housing pollcies ihat the rectplent can demonsurate are essential to the housing protram or activity will not be resprded-s discriminators withlo the meantins of this section 1 modifictions to them would result in fundamental alter. ation in the nature of the program or activity or undue finencial and admintstrative burdens.

$$
\text { Subpes O-Enforcanent }
$$

\subsection{Andurancen required.}

(8) Asrurances An applicant for Federal finnnoth asaterence for a prosram or activity to which this part applies shall submit an assurance to BOD. Or in the case of a subrectplent $10 \mathrm{a}$ pr. mary recipient. on a form spectified by the responsible civil rights official, that the program or activity will be operated in compliance with thls part. An applicant may incorporate these assurances by reference in subsequent applications to the Department.

(b) Duration of obligation (1) In the case of Federal financial assiatance extended in the form of real property or w provide real property or structures on the property, the assurance will obHote the recipient or, in the case of a subsequent transfer, the transferee. for the period during which the real property or structures are used for the purpose for which Federnl finencial asdetunce is extended or for snother purpose. Involving the proviston of similine services or benellth.

(2) In the case of Pederal Itnanclal assistance extended to provide personal property, the sesurance will obusate the reciptent for the period during whleh it retuins ownershlp or possession of the property.

(3) In 11 other cases the assurance will oblisate the recipient for the period during which Federal tinancial asaistance is extended.

(c) Covenants. (1) Where Federal 11 . nancial assistance is provided in the form of real property or tnterest in the properts from the Department. 


\section{HANDICAP VERIFICATION}

\section{Jear sirimadam.}

joecial considerations in tederally assisted nousin. are autnorized oy law lo a person or family oi a person wno is physically nandicapped. For ine puroose of qualitying ior inis supplement in rent. the nead of the nousenold or spouse must have a onysical impairment which (a) is expected to be of long-conilnued and indetinile duration. (o) suosiantially impedes nis/her abllily to live independenlly, and (c) is of such a nature inal such ability could be improved by more suilable nousing condilions.

Ve would appreciaie vour complelıng ine cerlificalion delow tor and relurning inis form in ine enclosed envelope. This intormation . vill be used only tor the purpose or classification and establishing eligidility for the supplemental payment.

Sincerely.

Manager

I hereby authorize the release of the requested intormation. 
isting of HUD muiti-iansip housing.

Handicap Listing

\begin{tabular}{|c|c|c|c|c|c|c|c|}
\hline iocation & $\begin{array}{c}\text { NUNBER } \\
\text { DE } \\
\text { JNITS }\end{array}$ & $\begin{array}{l}\text { JANDICAP } \\
\text { JNITS }\end{array}$ & $\begin{array}{l}\text { Handi } \\
\text { atfic }\end{array}$ & $\begin{array}{l}\text { iandi } \\
1 \text { Bed }\end{array}$ & $\begin{array}{l}\text { Hand } 1 \\
2 \text { Bed }\end{array}$ & $\begin{array}{l}\text { Handi } \\
3 \text { Bed }\end{array}$ & $\begin{array}{l}\text { CENSOS } \\
\text { TRACK }\end{array}$ \\
\hline - & -...-- & $-\ldots . .-$ & $-\cdots$ & -.... & $-\cdots$ & & --- \\
\hline :390 House & 53 & 0 & & & & & 08 \\
\hline ¿amrai Terrace (Pam) & $\$ 52$ & $\hat{\imath}$ & & & 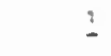 & 1 & 27 \\
\hline Arron Briggs & 38 & $?$ & & 9 & & & 12 \\
\hline Eardara Jordon Apt. (Fan) & 193 & 3 & & & & & $129-0964-0 !$ \\
\hline Barbara Jordon II (?am) & 76 & 0 & & & & & Rehab Coumt \\
\hline Beneficent house & 179 & 0 & & & & & 08 \\
\hline 8raeburn Apartments & 51 & 1 & & & 1 & & 28 \\
\hline Branch Apartments (Pam) & 18 & 0 & & & & & 10 \\
\hline Bridg̣ham Manor & 88 & 9 & & 3 & 1 & & 10 \\
\hline Eroadway Plaza (Pam) & 96 & 0 & & & & & 10 \\
\hline Cathedral Square I & 100 & 3 & & 8 & & & 08 \\
\hline Cathedral square II & 93 & 5 & 4 & 1 & & & 08 \\
\hline Chad Brown (Pan) & 198 & 3 & & & $?$ & 1 & 27 \\
\hline Eharles Place & 200 & 11 & & 11 & & & 23 \\
\hline Chari esgate Square East & 100 & 18 & & 9 & 9 & & 30 \\
\hline Charlesgate Square Norta & 200 & -4 & $i 2$ & 12 & & & 30 \\
\hline Chariesgate Square South & 100 & 12 & & 6 & 6 & & 30 \\
\hline Chatham Village (Fam) & 40 & 3 & & & & & 29 \\
\hline Codding Coure (zan) & 119 & 0 & & & & & 12 \\
\hline Colonial House & 101 & 3 & & 7 & 1 & & 02 \\
\hline Curtis arms & 106 & 10 & & 10 & & & 13 \\
\hline Dexter Manor I & 200 & 0 & & & & & 08 \\
\hline Dexter Hanor II & 31 & 10 & & 9 & 1 & & 08 \\
\hline Domusica Manor & 204 & 0 & & & & & 09 \\
\hline East Side Apartments & 82 & 3 & & 8 & & & 31 \\
\hline Edward Cooner house & 27 & 0 & & & & & 28 \\
\hline Etta Apartments (E!der!y) & 36 & 0 & & & & & 28 \\
\hline Evergreeo/Pleasant Apt. ( $\mathrm{Pan}$ ) & 65 & 0 & & & & & 32 \\
\hline Pather Parenti Villa & 198 & 0 & & & & & 10 \\
\hline Pox Point Manor & 98 & 7 & & 7 & & & 37 \\
\hline Grace Church Apartmeats & 100 & 6 & & 6 & & & 08 \\
\hline Grandriew Apartments & $g$ & 1 & & 1 & & & 31 \\
\hline Hagan Manor & 80 & 0 & & & & & 29 \\
\hline Hartford Park (Pam) (EId) & 392 & 8 & & & 4 & 3 & 18 \\
\hline Hartford Park EIt. (Pam) & 116 & 0 & & & & & 18 \\
\hline Harwoi Court (Pan) & 22 & 0 & & & & & 02 \\
\hline Millcrest Village & 130 & 18 & & 12 & 6 & & 20 \\
\hline Runtington Towers & 106 & 0 & & & & & 14 \\
\hline Indian Village ( $\mathrm{Fam}$ ) & 36 & 0 & & & & & 07 \\
\hline J. P. Carroll Towers & 198 & 0 & & & & & 27 \\
\hline John 0. Kilmartin, jr. & 106 & 0 & & & & & 14 \\
\hline Lockwood Plaza (Elderiy) & 101 & 4 & & 4 & & & 07 \\
\hline Lockwood Plasa (Pam) & .08 & 0 & & & & & 07 \\
\hline Yanton Helghts (Fam) & 330 & 14 & & 3 & 6 & 5 & 20 \\
\hline Maplewood Terrace (Ram) & 111 & 4 & & & 4 & & 28 \\
\hline Marvin Gardens I & 121 & 15 & & 12 & 3 & & 13 \\
\hline Marvin Gardens II & 24 & 15 & & 12 & 3 & & 13 \\
\hline Yedina Village & 83 & 2 & & 2 & & & $40-13 \quad 43-14$ \\
\hline Meirose Apartments & 42 & 2 & & 2 & & & 02 \\
\hline Metcaif Court I & 60 & 7 & & 6 & 1 & & 28 \\
\hline
\end{tabular}


isting of HUD multz-family nousing.

تandicap̣ Listing

\begin{tabular}{|c|c|c|c|c|c|c|c|}
\hline :ocation & $\begin{array}{c}\text { YUNBER } \\
\text { OP } \\
\text { UNITS }\end{array}$ & $\begin{array}{l}\text { HANDICAP } \\
\text { INITS }\end{array}$ & $\begin{array}{l}\text { handi } \\
\text { Iffic }\end{array}$ & $\begin{array}{l}\text { Handi } \\
1 \text { Bed }\end{array}$ & $\begin{array}{l}\text { Handi } \\
2 \text { Bed }\end{array}$ & $\begin{array}{l}\text { Handi } \\
3 \text { Bed }\end{array}$ & $\begin{array}{l}\text { CEYSUS } \\
\text { TRACK }\end{array}$ \\
\hline Yetcalí Court II & $\cdots-$ & $\cdots+\cdots$ & $\cdots$ & --- & $\cdots$ & $-\cdots$ & 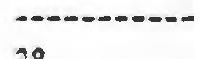 \\
\hline Yetcalt Court II & 52 & 6 & & 5 & : & & 28 \\
\hline Ht. Hope Court (Fam) & $\vdots 5$ & 3 & & & & & 31 \\
\hline Vew Cit7 Apartments (?am) & 99 & 0 & & & & & $50-05 \quad 45-04$ \\
\hline Olney Tawers & $\therefore 54$ & $\therefore$ & $\therefore 1$ & $\therefore 1$ & & & 19 \\
\hline oxford Place & 78 & 3 & & 5 & 3 & & 05 \\
\hline ?ark Hest & 100 & 9 & & 8 & 1 & & 01 \\
\hline ?arkis Place & 108 & 18 & 9 & 9 & & & 03 \\
\hline Pierce Manor & 83 & 8 & & 8 & & & 03 \\
\hline Pocasset Manor & 82 & 8 & & 7 & 1 & & 16 \\
\hline River Edge Village & 99 & 11 & & 10 & 1 & & 20 \\
\hline Poger Williams Home (Pan) & 40 & 0 & & & & & 05 \\
\hline Scattered Sites (Pam) & 252 & 12 & & & & 12 & \\
\hline Stratford House & 65 & 4 & & 4 & & & 02 \\
\hline Sunset Village & 24 & 2 & & 2 & & & 27 \\
\hline The Colong & 17 & 0 & & & & & 03 \\
\hline The Renalssance & 105 & 0 & & & & & 09 \\
\hline Jniversity Heights (Pan) & 102 & 0 & & & & & 31 \\
\hline Villa Ercelsior & 76 & 2 & & & 1 & 1 & 31 \\
\hline Westminster P!ace & 149 & 15 & & 14 & 1 & & 07 \\
\hline Wiggın Village (Pam) & 285 & 0 & & & & & 12 \\
\hline 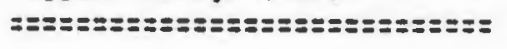 & $==s=s$ & 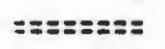 & $==\Sigma==$ & $== \pm==$ & $====\Omega$ & $== \pm==$ & $z=z=z=z=z=0$ \\
\hline & 7633 & 366 & 36 & 248 & 58 & 23 & \\
\hline
\end{tabular}


APPENDIX D

TABLE E Methodology

To estimate the pnysically disabled, income eifgible population or Erovidence over the next few years a projection nethodology was developed to determine the size of the disabled onpuiation in -989 and iga4. The rotais arrived at zy zas nethod are iNOT to be assumed to be that portion of the disabled population that would need a wheelchair accessible dwelling unit. mey are, rather, that broad group that covers all degrees of physical disability.

The three source documents used in this analysis were:

(A) U.S. Census, 1980

(B) Rhode Island Census of Disabled Persons, 1980 This document was compiled by The Governor's Committee on Employment of the Handicapped.

(C) D\&B - Donnelley Demographics, 1988 This file is produced annually by Donnelley Marketing Information Services, a company of the Dun \& Bradstreet Corporation. Donnelley Marketing Information Services has developed its own system for estimating currentyear demographics and projecting demographic trends five years into the future.

The following steps were carried out:

1. Establish disabled population for Prov, 1980 $21.8 \%$ (B) of 156,804 (A) $=34,183$

2. Estimate portion of Erovidence population, 1980, at or below $80 \%$ of Median Income.

a. Median HH income, $1980=\$ 11,545$ (A)

b. $80 \%$ of Median $\mathrm{HH}$ income, $1980=\$ 9,236$ (A)

c. Estimate \# of HH's earning at or below $\$ 9,236=$ $29,000 \mathrm{HH}$ 's, Prov, 1980 ( $\mathrm{A})$

d. Estimate portion of HH's zt or below $80 \%$ of median income $=29,000 / 60,157(1$. total \# of HH's in Prov., 1980$) \times 100=48.2 \%$

e. Convert HH figure in 2.d. to a population figure:

Multiply $29,000 \times 2.4$ (average $H H$ size in Prov, 1980. (A) to obtain number of people at or below $80 \%$ median income $=69.600$ people 
3. Estimate the proportion of Providence disabled population, 1980, at or below $80 \%$ of median income:

a. Estimate disabled population of Providence by multiplying the actual population 156,804 (A) $\mathrm{x}$

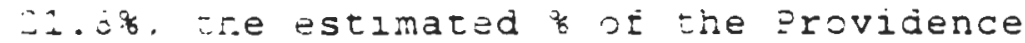
population which is disabled $(B)=34,183$

b. Hold constant the reiationsnip of income eiigible and disabled individuais to all income eligible individuais in the general population: apply $48.2 \%$ (2.d. estimate portion of HH's at or below $80 \%$ of median incomel to the number of disabled individuals in Prov., $1980(34,183)$ $\$ 4,183 \times .482=15,476$

4. Estimate that portion of the eligible, disabled population which is physically disabled, (not health or mentally disabled): multiply that estimated portion of the disabled popuiation. $53.8 \%$ (B) by the estimated number of disabled people, $16,476=8,864$.

E. For 1989 estimate of income eligible, physically disabled people:

a. Hold constant the $1.6 \%$ estimated increase in the general population (C) to the income eligible population: $16.476 \times 1.016=16.740$

b. Multiply $16,740 \times 53.8 \%$ as in step $4=9,006$

6. For 1994 projection of income eligible, physically disabled people:

a. Hold constant the .33\% (C) increase in population $16,740 \times 1.0033=16,795$

b. Multiply $16,795 \times 53.8 \%$ as in step 5.b. $=9,036$ 